\title{
Emeishan Basalt Ar-Ar overprint ages define several tectonic events that affected the western Yangtze platform in the Mesozoic and Cenozoic ${ }^{\text {is }}$
}

\author{
Jason R. Ali ${ }^{\mathrm{a}, *}$, Ching-hua Lo ${ }^{\mathrm{b}}$, Gary M. Thompson ${ }^{\mathrm{a}}$, Xieyan Song ${ }^{\mathrm{a}, \mathrm{c}}$ \\ ${ }^{a}$ Department of Earth Sciences, University of Hong Kong, Pokfulam Road,Hong Kong, People's Republic of China \\ ${ }^{\mathrm{b}}$ Department of Geosciences, National Taiwan University, 245 Choushan Road, Taipei 106, Taiwan, ROC \\ ${ }^{\mathrm{c} C e n t r e}$ for Analyses and Research, Chengdu University of Technology, Chengdu, 610059 Sichuan, People's Republic of China
}

Received 3 December 2002; accepted 25 February 2003

\begin{abstract}
$\mathrm{Ar}-\mathrm{Ar}$ whole-rock dating was carried out as part of a detailed stratigraphical investigation of the Emeishan Basalt large igneous province (LIP) in the stratotype area, Sichuan, China. Thirteen (from twenty-one) specimens from three sections yielded reliable reversed isochron and plateau ages (maximum $1 \sigma$ errors of $\leq 2.1$ and 1.6 m.y., respectively), and form two clusters centered on the Late Jurassic-Early Cretaceous and Early-Late Cretaceous, with a tail spanning 82-40 Ma. However, all are appreciably younger than the magnetobiostratigraphicallyconstrained late Middle Permian (255-260 Ma) age of the basalts, reflecting varying degrees of thermal resetting during the Mesozoic and Cenozoic. Recently, Middle Jurassic-Early Cretaceous ages reported from elsewhere in the LIP have been used to infer a single $40 \mathrm{~m} . \mathrm{y}$.-long tectonic episode that affected the western Yangtze Platform. Developing this idea, the new information have been combined with data we hold for other parts of the terrain, and results from three Emeishan LIP Ar-Ar dating studies published during 2002, to give 32 reliable age dates. Three 10-12 m.y. events appear to be recorded in different parts of the province: Middle Jurassic, Late Jurassic-Early Cretaceous and Early-Late Cretaceous, with a fourth shorter middle Eocene episode (the $40 \mathrm{~m} . \mathrm{y}$. Mesozoic episode appears to be a sampling artifact). Following a review of the regional deformation/tectonic features, it is argued that activity related to various phases of deformation in the Longmen Shan Thrust Belt is the most likely cause of resetting. The final suturing of the North and South China blocks may have also been responsible for the Middle Jurassic event. However, the Oligocene-present indentation of India into Asia appears not to have had an impact, possibly due to the large-scale related strike-slip faults that have effectively shielded the LIP/Sichuan Basin.
\end{abstract}

(C) 2003 Elsevier Ltd. All rights reserved.

Keywords: China amalgamation; Collision; Longmen Shan; Tectonic resetting

\section{Introduction}

The Emeishan Basalt large igneous province (LIP) sits on the western edge of the Yangtze platform (Fig. 1). Over the past decade, a considerable amount of research has been reported from the terrain with a main focus on (i) the

\footnotetext{
Recent U-pb SHRIMP dating work on Proteozoic rocks exposed in the southwest sector of the Longmen Shan thrust belt $\left(\sim 101.6^{\circ} \mathrm{E}, 28.6^{\circ} \mathrm{N}\right)$ has identified $177 \pm 3$ Ma metamorphic growth rims on zircon crystals associated with movement along a core complex detachment fault (Yan et al., 2003). The new data are consistent with the Middle Jurassic tectonic event proposed herein. In fact, the Middle Jurassic Ar-Ar reset age dates are from the immediately adjacent 'West of Centre' portion of the Emeishan LIP.

* Corresponding author. Tel.: + 86-852-2857-8248; fax: + 86-852-25176912.

E-mail address: jrali@hkucc.hku.hk (J.R. Ali).
}

mechanism that generated the LIP (e.g. Luo et al., 1990; Dmitriev and Bogatikov, 1996; Chung and Jahn, 1995; Thompson et al., 2001; Xu et al., 2001), and (ii), the link of the LIP to the two mass extinctions that occurred within 8$10 \mathrm{~m} . \mathrm{y}$. of one another in the latter part of the Permian (Zhou et al., 2001, 2002; Ali et al., 2002; Lo et al., 2002). A key aspect of these studies has been establishing the age and duration of volcanism. Regional biostratigraphic studies suggest that the unit is of late Guadalupian (Middle Permian) age (e.g. Sheng and Jin, 1994; Jin and Shang, 2000). Magnetostratigraphic studies (e.g. Huang and Opdyke, 1998) suggest that the bulk of the basalt pile was erupted geologically very quickly; Ali et al. (2002) tie the main part of the lava pile to a single normal polarity field state that terminated about $1 \mathrm{~m} . \mathrm{y}$. prior to the end of the Guadalupian. 


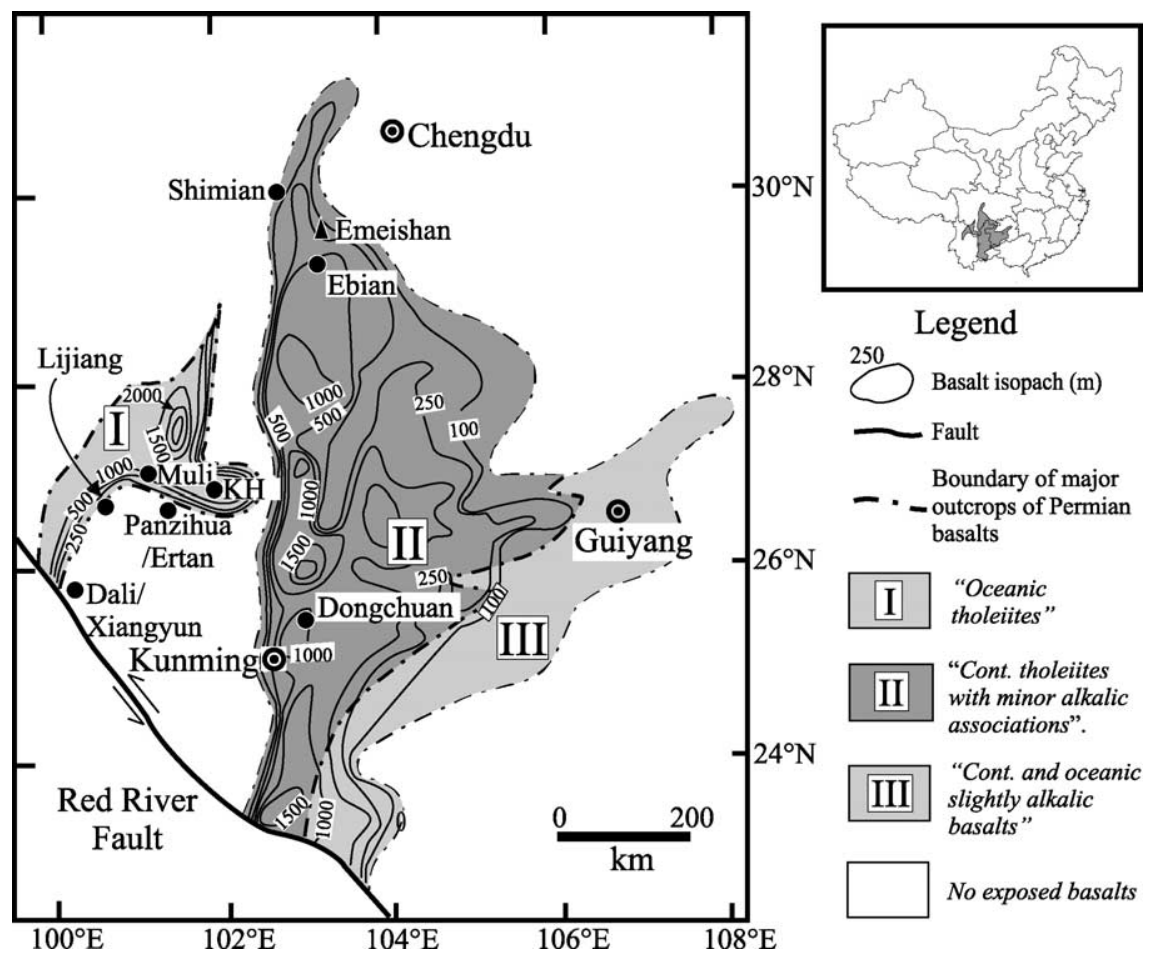

Fig. 1. Map showing the areal extent of the Emeishan Basalts (based on Liu and Xu, 1994) and localities mentioned in the text.

Over the past year, the results of several radiometricdating studies have been reported from the LIP. Possibly the most sensible age $(\sim 259 \mathrm{Ma})$ has been obtained from $\mathrm{U}-\mathrm{Pb}$ SHRIMP studies of zircon grains from intrusive rocks thought to be directly associated with the LIP (Zhou et al., 2001, 2002); the numerical age clearly ties in with a late Guadalupian fossil-age. In terms of direct dating of the Emeishan Basalt flows, several Ar-Ar studies, with varying degrees of success, have been reported (Boven et al., 2002; Lo et al., 2002; Hou et al., 2002). Some results showed a range of formation ages from the endMiddle to late Late Permian (258.9-251.5 Ma), but some others yielded disturbed isotope systematics resulting in Meso-Cenozoic ages. These abnormally young ages have tentatively been interpreted as a result of thermal resetting due to Mesozoic and Cenozoic tectonothermal events (Boven et al., 2002; Lo et al., 2002). Nevertheless, Hou et al. (2002), working on sections in the western and southwestern parts of the LIP, interpreted a series of anomalously young dates $(177-135 \mathrm{Ma})$ to mark a single tectonothermal episode related to the collision of one or more crustal blocks with the western Yangtze platform in the Middle Jurassic-Early Cretaceous.

In a study of sections close to the Emeishan Basalt stratotype area (Fig. 1) a twenty-one aphyric basalt samples were chosen for $\mathrm{Ar}-\mathrm{Ar}$ whole-rock analysis. The results from these studies, as well as the other recently published results, have a bearing on the cause of the resettings and their possible link to regional tectonic events.

\section{Analytical methods}

The samples (comprising $\sim 2 \mathrm{~mm}$ diameter whole-rock chips) were wrapped in aluminum foil packets, stacked in an aluminum canister with three aliquots of the irradiation standard LP-6 biotite (Odin et al., 1982) and irradiated in the VT-C position of the Tsing-Hwa THOR research reactor for $30 \mathrm{~h}$. The neutron flux gradient across the top and bottom of the irradiation canisters was less than $0.9 \%$, as indicated by the variation of $\mathbf{J}$ values from the flux monitors. An average value of the $\mathbf{J}$ values is adopted in the age calculations.

After irradiation, the samples were loaded into fusedsilica boats, and heated with a Lindberg resistance furnace. The released gas was purified with a Ti sponge and two $\mathrm{Zr}-$ Al getters, and analyzed with a Varian-MAT GD150 mass spectrometer at the National Taiwan University. Measured isotopic ratios were corrected for the effects of mass discrimination, system blanks, radioactive decays and interfering isotopes produced during irradiation using factors reported by Lo and Lee (1994). Apparent ${ }^{40} \mathrm{Ar} /{ }^{39} \mathrm{Ar}$ ages were calculated from the corrected isotopic ratios using decay constants and isotopic abundance ratios given by Steiger and Jäger (1977). Integrated dates were computed from the sum total of the peak heights, and their errors from the square root of the sum square of the peakheight errors, for all of the temperature steps. Plateau dates were calculated by the same approach, but utilized only those contiguous steps yielding dates, which do not differ at 
Table 1

Summary of Ar-Ar data from the Emeishan area in a stratigraphic context. In the Lith. Unit column, F = flow, $12=$ flow 12 , b/l/m $=$ base/lower/middle. The errors are $1 \sigma$ values and include uncertainties derived from the age of the irradiation standard. ND $=$ no data

\begin{tabular}{|c|c|c|c|c|c|c|c|c|c|}
\hline Site & Lith Unit & Ht. in unit (m) & $\mathrm{Ht}$ in $\mathrm{sec}(\mathrm{m})$ & Integ. Date (Ma) & Error, \pm & Rev Isoc. Age (Ma) & Error, \pm & Plateau, Date (Ma) & Error, \pm \\
\hline \multicolumn{10}{|c|}{ Locality $=$ Xin Chung; Long $=103^{\circ} 16.466^{\prime}$; Lat $=29^{\circ} 17.933^{\prime}$. } \\
\hline $\mathrm{XC} 12.2$ & F-12-m & 10 & 169 & 147.4 & 1.6 & 139.1 & 2.1 & 143.3 & 1.6 \\
\hline $\mathrm{XC} 11.5$ & F-12-1 & 2 & 161 & 136.4 & 1.4 & ND & ND & ND & ND \\
\hline XC9.2 & F10-m & 6 & 142 & 92.8 & 1.0 & 93.3 & 1.2 & 92.9 & 1.0 \\
\hline XC8.6 & F10-1 & 3 & 139 & 70.1 & 0.8 & 61.7 & 0.8 & 61.2 & 0.7 \\
\hline XC7.2 & F-9-m & 10 & 127 & 93.4 & 1.0 & 95.1 & 1.4 & 95.1 & 1.0 \\
\hline $\mathrm{XC} 4.3$ & F-8-1 & 3 & 98 & 90.3 & 0.9 & ND & ND & ND & ND \\
\hline $\mathrm{XC} 3.3$ & F-7-m & 12 & 73 & 66.9 & 0.7 & 57.3 & 0.6 & 56.8 & 0.6 \\
\hline XC2.3a & F-7-1 & 5 & 66 & 80.2 & 0.8 & 77.8 & 1.2 & 76.9 & 0.8 \\
\hline \multicolumn{10}{|c|}{ Locality $=$ Ebian; Long $=103^{\circ} 16.392^{\prime}$; Lat $=29^{\circ} 16.139^{\prime}$. } \\
\hline EB7.2 & F-7-b & 2 & 63 & 143.1 & 1.4 & 146.5 & 1.8 & 146.9 & 1.5 \\
\hline EB6.3 & F-6-b & 4 & 59 & 72.0 & 0.8 & ND & ND & ND & ND \\
\hline EB5.5a & F-5-b & 2 & 47 & 96.3 & 1.0 & 94.5 & 1.7 & 96.7 & 1.0 \\
\hline EB3.4b & F-3-b & 1.5 & 22.5 & 99.2 & 1.0 & 100.6 & 1.3 & 100.9 & 1.1 \\
\hline \multicolumn{10}{|c|}{ Locality $=$ Qing Yin power station, Emeishan; Long $=103^{\circ} 24.518^{\prime}$; Lat $=29^{\circ} 34.671^{\prime}$. } \\
\hline EM34.3 & F-12-u & 15 & 265 & 70.1 & 0.8 & ND & ND & ND & ND \\
\hline EM27.1 & F-12-1 & 5 & 255 & 87.7 & 0.9 & ND & ND & ND & ND \\
\hline EM26.5a & F-9-m & 12 & 185 & 173.4 & 1.9 & ND & ND & ND & ND \\
\hline EM31.2b & F-8-m & 12 & 160 & 199.7 & 2.3 & ND & ND & ND & ND \\
\hline EM21.1 & F-6-1 & 1 & 121 & 52.7 & 0.7 & 53.2 & 1.1 & 53.1 & 0.6 \\
\hline EM20.4 & F-5-u & 20 & 115 & 66.4 & 0.7 & ND & ND & ND & ND \\
\hline EM17.4 & F-3-m & 12 & 55 & 71.7 & 0.8 & 68.9 & 1.9 & 70.9 & 0.8 \\
\hline EM10.4 & F-2-u & 32 & 40 & 43.9 & 0.5 & 45.9 & 1 & 45.7 & 0.5 \\
\hline
\end{tabular}

$2 \sigma$ level. In the ${ }^{36} \mathrm{Ar} /{ }^{40} \mathrm{Ar}-{ }^{39} \mathrm{Ar} /{ }^{40} \mathrm{Ar}$ correlation diagrams, the cubic least-squares fitting scheme outlined by York (1969) was employed to regress the data. The regression line yields two intercepts; the inverse of ${ }^{39} \mathrm{Ar} /{ }^{40} \mathrm{Ar}$ intercept produces a so-called intercepted date, whereas the inverse of the ${ }^{36} \mathrm{Ar} /{ }^{40} \mathrm{Ar}$ intercept indicates the composition of a nonradiogenic argon component. One standard deviation, intralaboratory uncertainties in each apparent age is reported. The analytical data are presented in Supplementary Data Table 1 (age spectra and ${ }^{36} \mathrm{Ar} /{ }^{40} \mathrm{Ar}-{ }^{39} \mathrm{Ar} /{ }^{40} \mathrm{Ar}$ correlation diagrams for each sample are available from JRA). Representative age spectra plots are presented in Fig. 2, and the total data set is summarized in Fig. 3 and Table 1. In selecting samples for geological interpretation only those yielding plateau ages have been used. However, for completeness those samples with only integrated ages are also listed.

\section{Results}

Three of the eight samples analyzed from the Qing Yin power station section (Table 1, Fig. 1: flank of Mt Emei, Fig. 3) yielded Late Cretaceous-middle Eocene plateau ages (70.9-45.7 Ma). The remaining five samples have a spread of integrated ages from Early Jurassic to terminal Cretaceous. Four of the five samples from the section near Ebian town (Table 1, Figs. 1 and 3) yielded plateau ages in the range 146.9-96.7 Ma. Two have Late Jurassic/Early Cretaceous ages, but these are physically separated by samples EB3.4b and EB5.5a that yielded ages close to Early/Late Cretaceous boundary. A fifth sample, EB6.3, yielded an integrated age of $72 \mathrm{Ma}$. At Xin Chung village, eight samples were analyzed from five flows. Plateau ages were obtained from six samples, with ages ranging between Late Jurassic and late Paleocene (143.3-56.8 Ma). Interestingly the two double-sampled flows (Flows 7 and 10) both gave two different ages separated by about $20 \mathrm{~m}$.y. The three samples with integrated ages only gave a similar spread to the plateau-age sample dataset.

In addition to the Emeishan area ages, one author (ChL) had a set of results from eight samples from various parts of the LIP. Unfortunately, only two samples, both from Guizhou Province, yielded reliable plateaus, both with ages around $42 \mathrm{Ma}$ (Table 2). Interestingly, three of the remaining six samples have similar middle Eocene integrated ages, the remaining three samples having ages ranging from the late Early Jurassic to early Eocene.

There appears to be no obvious patterns to the data. None of the Emeishan area sections carry similar ages throughout, and where ages from dual flow samples have been obtained there appear to be discrepancies. However, 

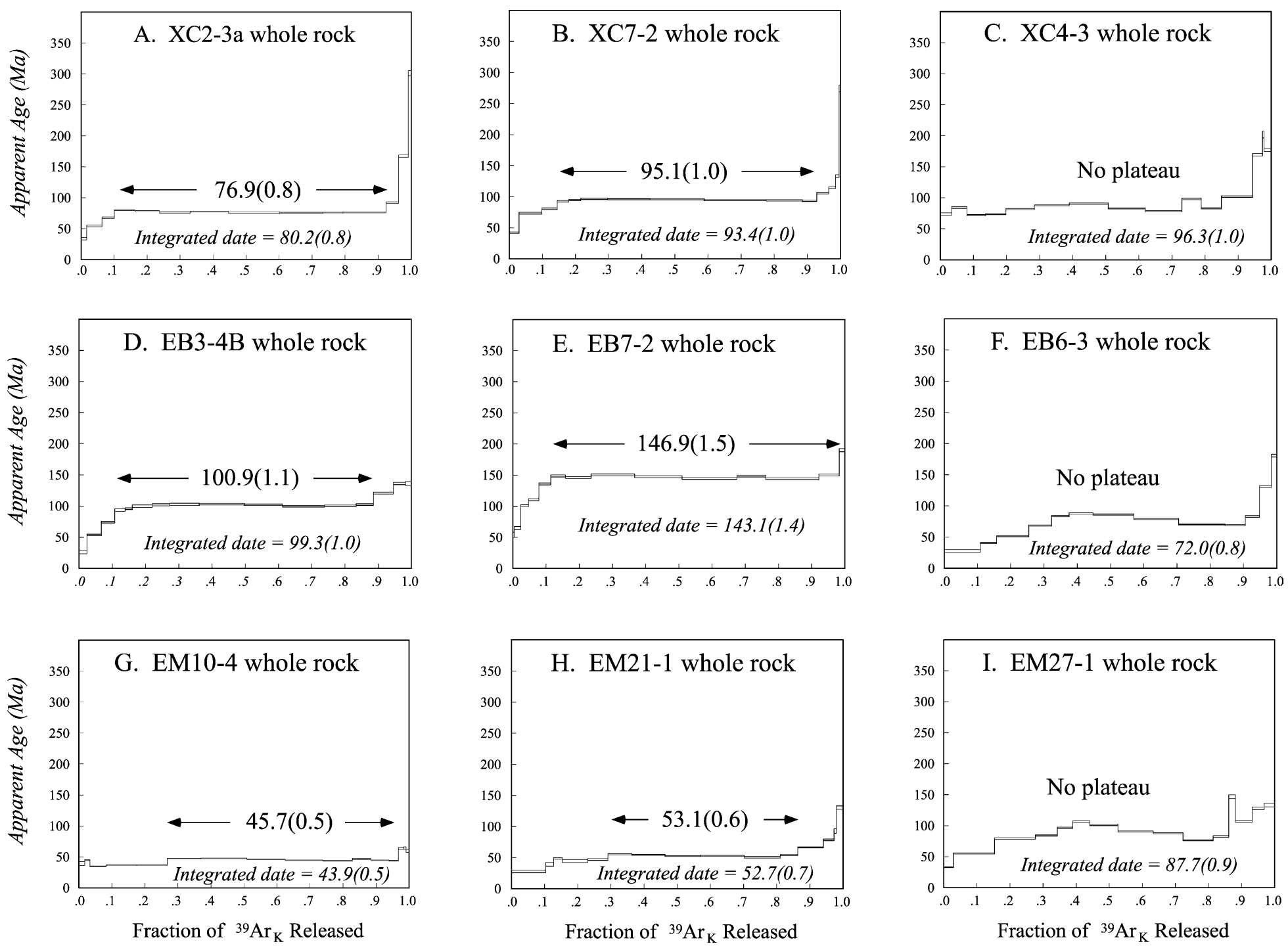

Fig. 2. Apparent age spectra of the furnace step-heating analyses for representative samples: a-c are from Xin Chung, $d-f$ are from Ebian, $g-i$ are from the Qing Yin power station. Samples yielding what are considered reliable plateau ages are shown in a,b,d,e,g,h. See Supplementary Data Table 1 for details. 


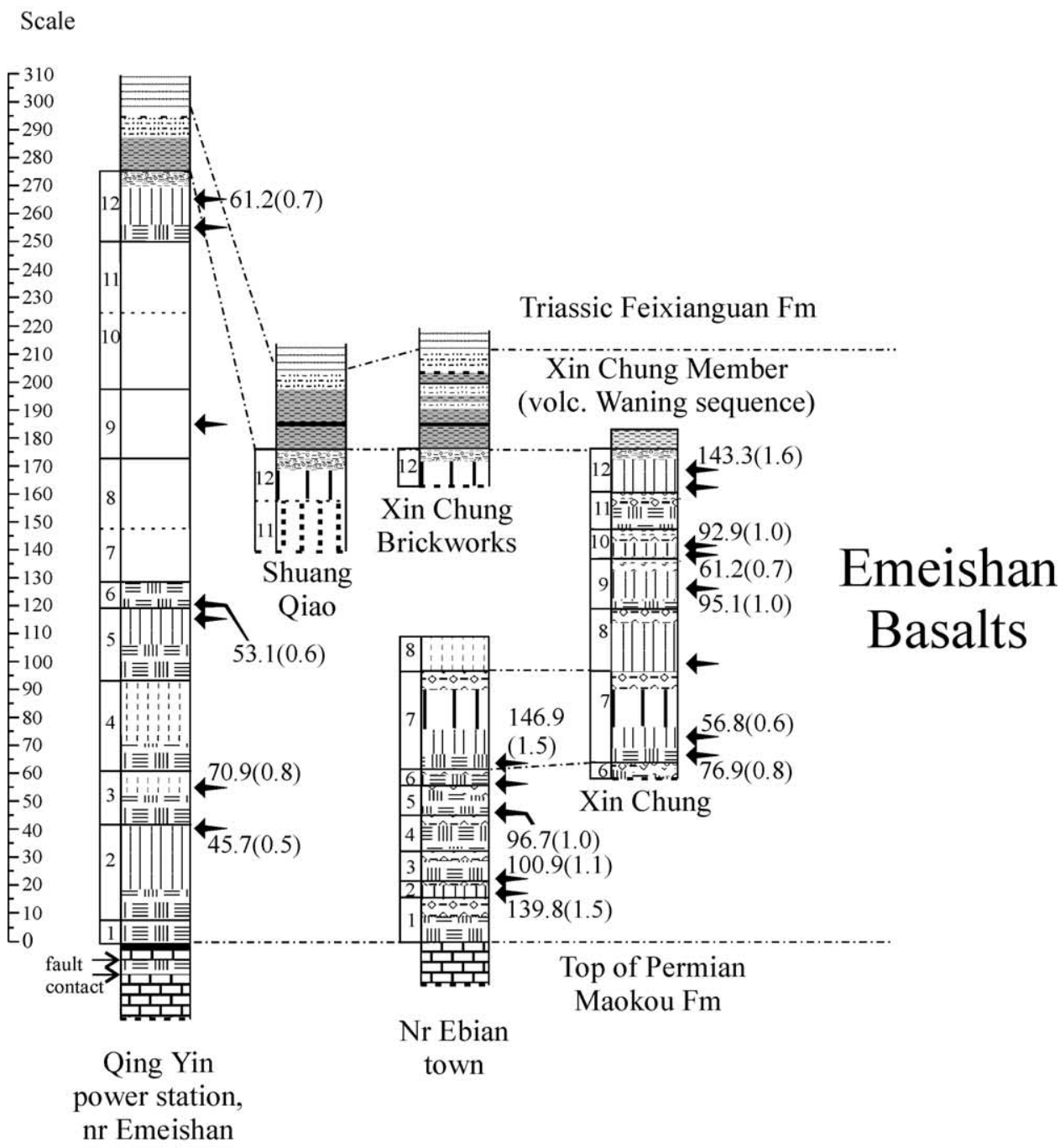

Lithologic Legend

\begin{tabular}{|c|c|c|c|}
\hline 三 & Triassic sediments & $0=0$ & Flow top \\
\hline & Lignite & $8::$ & Basalt pseudo-colonnades \\
\hline 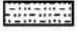 & Sandstones/mudstones & 4 & Basalt colonnades - \\
\hline & $\begin{array}{l}\text { Inter-layered pyroclastics } \\
\text { and weathered basalts }\end{array}$ & 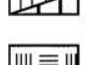 & $\begin{array}{l}<0.3 \mathrm{~m} />0.3 \mathrm{~m} \text { colonnades } \\
\text { Basalt entablatures }\end{array}$ \\
\hline 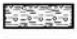 & Paleo-weathered flow top & & I i \\
\hline rovg & Rubbly flow top & & Lime \\
\hline
\end{tabular}

Fig. 3. Stratigraphic summary of the sections in Ebian County and the Mt Emei area with the obtained Ar-Ar at specific levels. Arrows with numbers next to the lithocolumns indicate the plateau age with the error shown in parentheses (also see Table 1). Arrows without numbers indicate sample levels for which a plateau date could not be obtained. Where flows are too poorly exposed to determine their internal structure (colonnades, etc.) they are left blank. Dashed lines indicate that the contact between flows or units is obscured or questionable. While twelve flows are recognized at both Emei and Ebian-Xin Chung, a flow-byflow correlation is not inferred.

for any sample to yield a reliable, but clearly post formation-age (derived from a plateau and/or reverse isochron age) there has to be some physical basis for its radiometric clock being reset. In fact Hou et al. (2002) recently used a series of Emeishan Basalt reset ages to infer a mid Mesozoic tectonic episode which affected the western Yangtze Platform. Therefore, with three batches of $\mathrm{Ar}-\mathrm{Ar}$ dates being recently published for the Emeishan
Basalts (Boven et al. 2002; Lo et al. 2002; Hou et al., 2002), together with our large dataset it was thought opportune to evaluate the Hou et al. (2002) model.

\section{Summary of other reported data}

Other age data obtained from the Emeishan LIP are listed in Table 3. Boven et al. (2002) published the first 
Table 2

Summary of previously unpublished $\mathrm{Ar}-\mathrm{Ar}$ age data obtained by $\mathrm{ChL}$ from other parts of the Emeishan LIP. The errors are $1 \sigma$ values and include uncertainties derived from the age of the irradiation standard. ND $=$ no data

\begin{tabular}{lllll}
\hline $\begin{array}{l}\text { Additional data } \\
\text { held by CHL }\end{array}$ & $\begin{array}{l}\text { Integ. } \\
\text { Date (Ma) }\end{array}$ & $\begin{array}{l}\text { Error, } \pm \\
\text { Plateau, } \\
\text { Date (Ma) }\end{array}$ & Error, \pm \\
\hline Guizhou Prov. EM-QN-04 & 42.0 & 1.1 & 40.2 & 1.0 \\
Guizhou Prov. EM-QN-04 & 41.4 & 1.1 & 41.4 & 1.1 \\
Guizhou Prov. EM-QN-18 & 40.8 & 1.0 & ND & ND \\
Dongchuan EM-E031 & 53.3 & 0.2 & ND & ND \\
Ertan EM-E881 & 42.2 & 0.2 & ND & ND \\
Ertan EM-E881 & 44.2 & 0.2 & ND & ND \\
Ertan EM-E901 & 137.4 & 0.4 & ND & ND \\
East of Ertan EM-E971 & 181.7 & 0.5 & ND & ND \\
\hline
\end{tabular}

$\mathrm{Ar}-\mathrm{Ar}$ dates with variable quality data reported from eleven samples. Using the criteria adopted in our studies, that is well-defined age-spectra plateaus with small associated standard deviations, six samples shown in their Fig. 2 (listed here in Table 3), are considered to yield geologically meaningful data. These include one formation age $(254.5 \pm 0.2 \mathrm{Ma})$ and five post-formation age samples. As part of the same study, Hou et al. (2002) presented reverse isochron ages for seven samples from the northern and western parts of the Emeishan LIP. One formation age $(258.9 \pm 3.4 \mathrm{Ma})$ was identified along with six Middle Jurassic-Early Cretaceous reset ages (see Table 3). It should also be noted that the sample-set is based on material from different parts of the LIP, from Mt Emei in the north to close to the Red River Fault near Dali.

Lo et al. (2002) presented a set of formation age dates (254.6-251.5 Ma) for samples from the western part of the LIP (see Table 3). It is noted that the ages are slightly younger than the likely numerical age of the Middle/Late Permian boundary (end of the Guadalupian) or Zhou et al. (2002) U-Pb zircon age data. Several explanations may explain the young dates: (i) volcanism in the western part of the LIP started and terminated in the Late, rather than late Middle, Permian, (ii) there is a problem with the mathematical constants used in the $\mathrm{Ar}-\mathrm{Ar}$ and/or $\mathrm{U}-\mathrm{Pb}$ dating systems, thus cross-calibrations lead to apparent errors, (iii) the $\mathrm{Ar}-\mathrm{Ar}$ dates reflect reset events that occurred a few to several million years after the basalts were erupted.

For illustrating the possible effects of post-formation tectonothermal events, all the available data for the Emeishan LIP are compiled in Fig. 4. As shown in Fig. 4, four age-clusters can be identified: a set of formation age samples at 259-251.5 Ma (1) and reset groups at \pm 175 (2), \pm 142 (3) and $\pm 98 \mathrm{Ma}(4)$. The claims for age clustering appear to be bolstered by some of the integrated age sample data, and a possible fifth cluster at $40-45 \mathrm{Ma}$ appears to emerge from the string of ages between 82 and $40 \mathrm{Ma}$. Aside from the clustering, the data-lows at 250-185, 172148, 137-104 and 40-0 Ma may also be significant.

Table 3

Summary of the 2002 published Ar-Ar age data from the Emeishan LIP (Boven et al. 2002; Lo et al. 2002; Hou et al., 2002; Zhou et al. 2002). In the 'Part of LIP' column, $\mathrm{N}=$ north; WoC = west of center; RR = near Red River Fault

\begin{tabular}{|c|c|c|c|c|c|}
\hline & Rev Isoc. Age (Ma) & Error, \pm & Plateau, Date (Ma) & Error, \pm & Part of LIP \\
\hline \multicolumn{6}{|l|}{ Selected data from Boven et al. (2002) } \\
\hline $250 \mathrm{~m}$ below summit of Mt Emei (Ch-97-05) & & & 82.0 & 1.0 & $\mathrm{~N}$ \\
\hline Kangdian High, Longmenshan TB (Ch-97-26) & & & 184.4 & 2.9 & WoC \\
\hline Xiaguan (Ch-97-90) & & & 254.5 & 0.2 & $\mathrm{RR}$ \\
\hline Ertan Dam (Ch-97-33) & & & 41.6 & 1.2 & WoC \\
\hline Wuben, nr Panzhihua (Ch-97-48) & & & 103.7 & 0.6 & WoC \\
\hline Wuben, nr Panzhihua (Ch-97-49) & & & 100.3 & 1.0 & WoC \\
\hline \multicolumn{6}{|l|}{ Data from Hou et al. (2002) } \\
\hline Panzihua (R-22) & 258.9 & 3.4 & & & WoC \\
\hline Lijang (JL-13) & 176.9 & 1.9 & & & WoC \\
\hline Ertan (R-1) & 172.3 & 2.2 & & & WoC \\
\hline Binchuan (BH-11) (near Xianguan - see above) & 148.2 & 1.5 & & & $\mathrm{RR}$ \\
\hline Shimian (SH-01) & 137.1 & 3.4 & & & $\mathrm{~N}$ \\
\hline \multicolumn{6}{|l|}{ Selected data from Lo et al. (2002) } \\
\hline Ertan (EM-90) & 256.2 & 0.9 & 251.5 & 0.9 & WoC \\
\hline Ertan (EM-86) & 252.1 & 1.3 & 252.8 & 1.3 & WoC \\
\hline Panzhihua Complex (EM-PZH01) & 246.1 & 1.3 & 254.6 & 1.3 & WoC \\
\hline Binchuan (EM-37) & 252.0 & 1.3 & 252.0 & 1.3 & $\mathrm{RR}$ \\
\hline Maomaogou Complex (EM-MMG05) & 252.0 & 1.3 & 252.0 & 1.3 & WoC \\
\hline Panzihua Complex EM-PZH11 & 251.6 & 1.6 & 251.6 & 1.6 & WoC \\
\hline \multicolumn{6}{|l|}{ U-Pb SHRIMP data from Zhou et al. (2002) } \\
\hline Xinje Intrusion & & & 259 & 3 & WoC \\
\hline
\end{tabular}



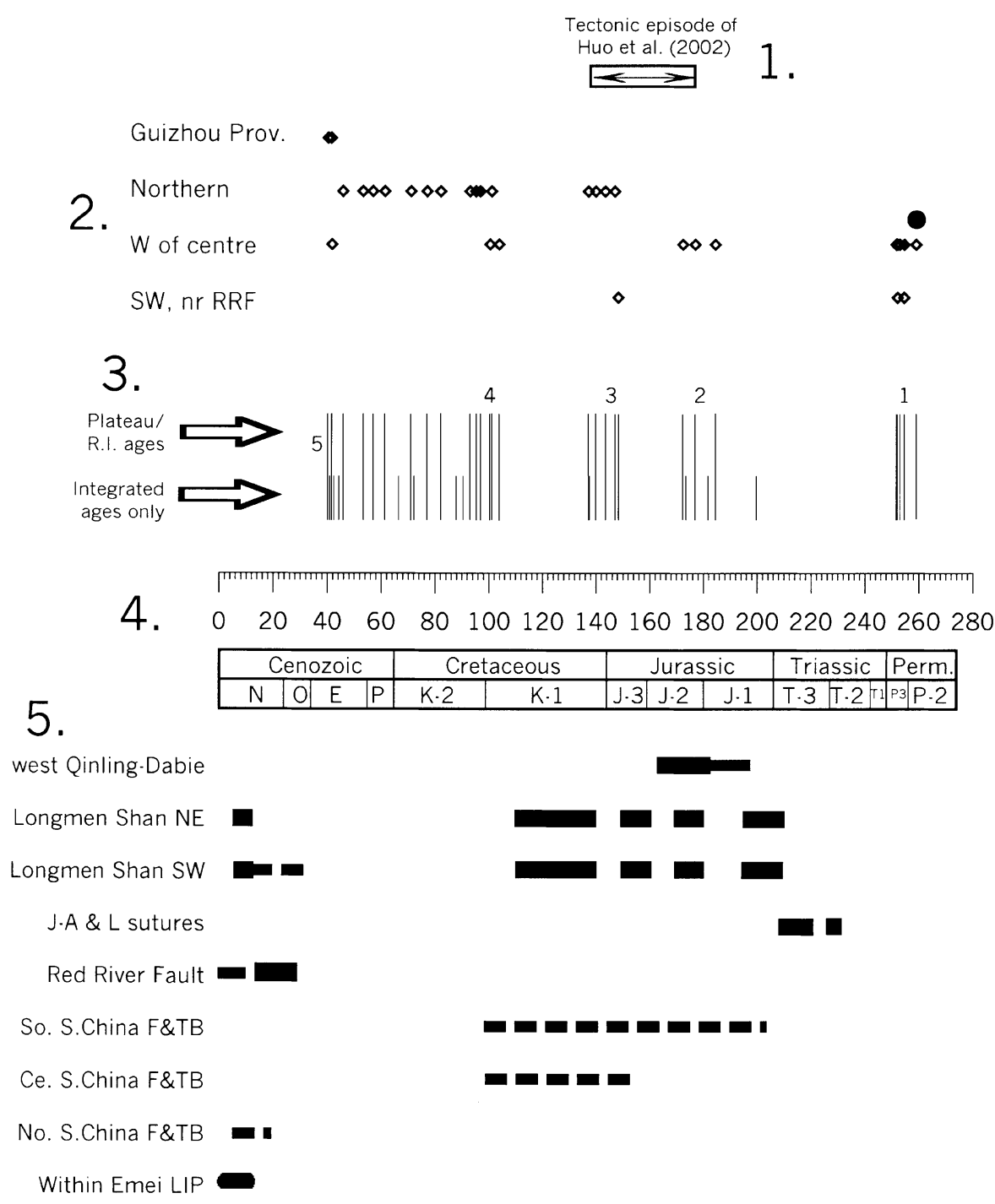

Fig. 4. Summary of Ar-Ar age data obtained from the Emeishan LIP. (1) The Middle Jurassic-Early Cretaceous tectonic episode of Hou et al. (2002). (2) Shows an age plot in which the samples with plateau/reverse isochron ages are separated into sub-provinces within the LIP (the zircon date of Zhou et al. (2002) is shown as the solid black circle). (3) Shows an age-sample barchart for samples with plateau/reverse isochron ages (tall bars) and integrated ages (for which no plateau or reverse isochrons could be obtained - short bars). (4) Is the geologic time-scale of Palmer and Geissman (1999). (5) Synthesis of regional tectonic events, the broad bars representing distinct events where the timing is tightly constrained. For systems where the age-control is somewhat limited (see text for details) dashed narrow bars are used. J-A and L sutures refers to the Jinshajiang-Ailoshan and Lancangjiang Sutures, F and TB indicates fold and thrust belts (in S. China)

Importantly, they suggest that the Middle Jurassic-Early Cretaceous tectonic episode of Hou et al. (2002) more likely represents two discrete events (Groups 2 and 3) with durations of 10-12 m.y. This is perhaps not surprising. Our knowledge of the individual collision systems in, for example, offshore SE Asia indicates that the activity occurs for a few to $10 \mathrm{~m}$.y. or so, but that the whole region (in effect the orogenic belt) may be active for 50-100 m.y, or even longer (e.g. Hall, 2002).

Another feature to emerge from Fig. 4 is the geographic control on the distribution of ages. For example, the west of center outcrops (triangle between Dali, Panzihua and Muli) and the area near to the Red River Fault are the only places where formation age dates are preserved. Also, the Middle Jurassic and middle Cretaceous events are recorded only in the west of center and northern parts of the province.

Finally perhaps the most puzzling aspect of the dataset is why do geographically close samples, and often in a single section, record different ages? Hou et al. (2002) imply that if a section was involved in a tectonothermal event, then the whole section would record a similar age. The expanded dataset appears to contradict this, suggesting instead that specific levels within a basalt pile outcrop may be reset at different times or, perhaps more likely, some levels may be reset once, whilst others are reset two or more times, in effect recording the last event. 

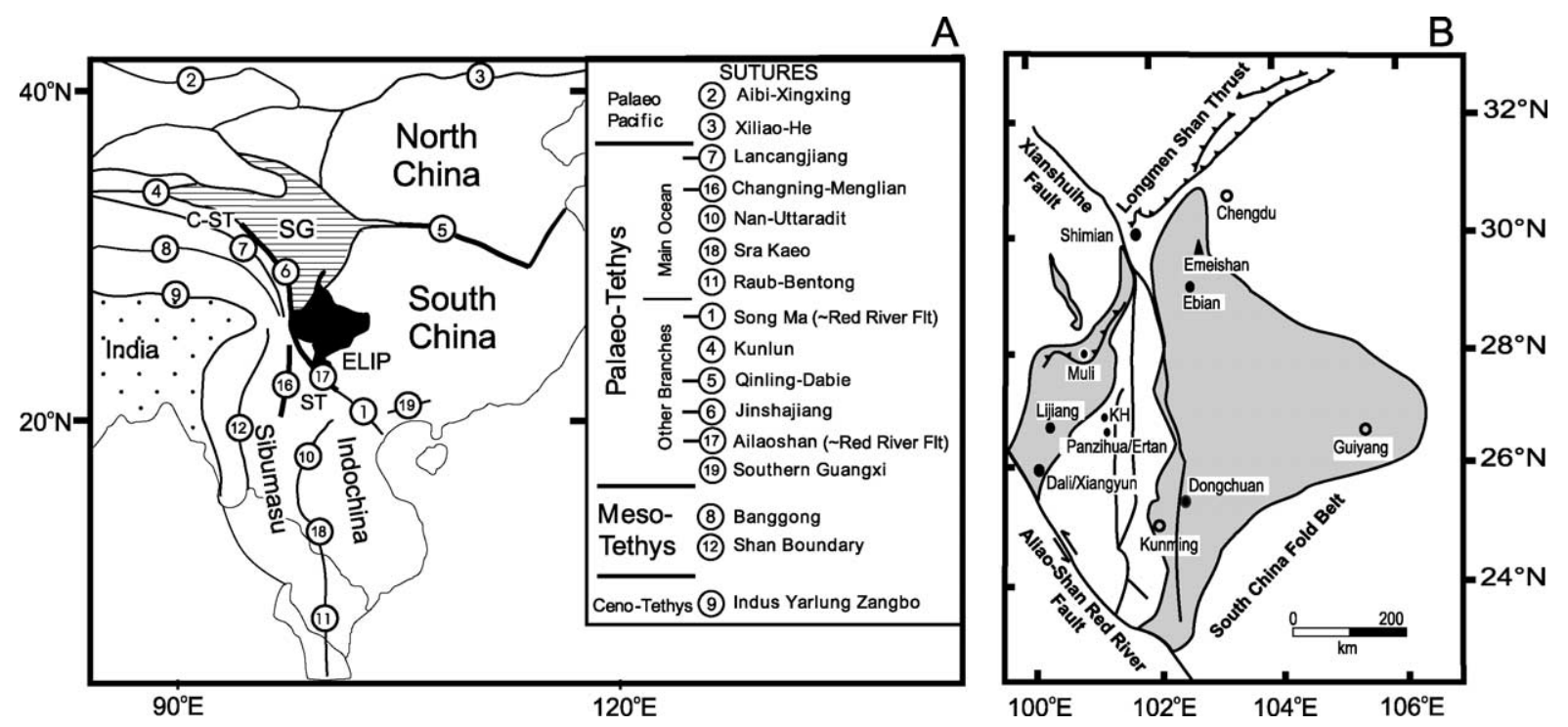

Fig. 5. (A) Map showing the crustal blocks and sutures of eastern Asia, based on Metcalfe (1999). (B.) more detailed sub-regional structural/tectonic boundary map based on Chen et al. (1995), Chen and Wilson (1996), Wang et al. (1998a) and Boven et al. (2002). The suture numbering scheme used in A has been retained from Metcalfe (1999). Note that several terranes and sutures are not shown, for example 13, Woyla suture. A number of the tectonic features shown in detail in B have also been added. The diamond-shaped shaded areas, black in A and grey in B, mark the approximate geographical extent of the Emeishan LIP (ELIP). Abbreviations KH, Kangdian High; ST, Simao terrane; C-ST Changdu-Simao terrane. Note that the Red River Fault follows the approximate line of the Ailoashan and Song Ma sutures. In the suture definition key, circled numbers with bars to the left indicate terrane boundaries mentioned in the text.

\section{Major adjacent tectonic boundaries}

In attempting to understand the distribution of ages, we have looked at East Asia terrane/suture maps (e.g. Metcalfe, 1999; see Fig. 5) and tectonic models that have been proposed for the sub-region (e.g. Chen and Wilson, 1996; Arne et al. 1997; Wang et al., 2000b). A number of tectonic boundaries/zones which, when active, could have reset the Emeishan Basalt radio-isotopic systems were identified. Working from NE of the LIP counter-clockwise, current knowledge of each structure is summarized below. In some cases events are known with a reasonable degree of precision. However, in many cases tectonic phases are constrained only by stratigraphic evidence and the associated error could be 10 or 20 m.y. Dating molasse, continental onlap sequences, erosion surfaces, etc. is notoriously difficult, as can be the problem of establishing the age of a rock unit based on a dated cross-cutting intrusive body.

\subsection{Qinling-Dabie suture}

Approximately $500 \mathrm{~km}$ to the north and northeast of the Emeishan LIP (Fig. 5) is the western part of the QinlingDabie suture, marking the boundary between the South and North China Blocks. Combined geological and palaeomagnetic data indicate that suturing commenced in the Permian and involved east to west scissor-like diachronous closure (e.g. Enkin et al., 1992; Zhao et al., 1996). According to Zhao et al. (1996), the blocks had amalgamated before the end of the Middle Jurassic (see also Gilder and Courtillot, 1997; Yokoyama et al., 1999), and might thus explain the reset ages at $\sim 175 \mathrm{Ma}$.

\subsection{Longmen Shan thrust belt}

The NE-SW striking Longmen Shan thrust system separates the Songpan-Garze flysch basin (Nie et al. 1994; Chang, 2000) from the stable Yangtze platform to the east (Wang et al. 1998a; Fig 4). The system is cut by the late Cenozoic Xianshuihe-Xiaojiang strike slip fault (see below). The system could be important for interpreting the Emeishan dates; the northeast thrust belt lies just to the north of the LIP whilst the one to the southwest cuts through the western flank of the LIP. Working on the northeastern belt, Chen and Wilson (1996) identified four periods of activity in the Mesozoic, which they related to discrete phases of magmatism in the Songpan-Garze fold belt at $210-195,180-170,160-150$ and $140-110 \mathrm{Ma}$. They also recognized a late Miocene reactivation event. In the southwest, Burchfiel et al. (1995) recognized a young deformation phase affecting 'upper Eocene-(?) Oligocene' rocks. We suggest that Cenozoic tectonism in this part of the thrust belt could have occured anytime between the Oligocene and late Miocene, but place a greater emphasis on the younger part of this range, which is reflected in Fig. 4.

\subsection{Jinshajiang-Ailoshan and Lancangjiang sutures}

East to west, the Jinshajiang-Ailoshan and Lancangjiang sutures separate the South China, Changdu-Simao and Sibumasu Blocks (Fig 5). The tectonic model of Wang et al. (2000b) provides key information. The ChangduSimao continent is a narrow fragment that separated from western South China starting in the Late Devonian, akin to SW Japan sitting offshore northeast Asia. 
The Changdu-Simao and Sibumasu Blocks sutured first, in the late Middle Triassic, followed by the Late Triassic collision of the composite terrane with South China. Neither event seems to have left its imprint on the Emeishan LIP.

\subsection{Red River Fault}

The Red River Fault separates the South China and Indochina Blocks. According to Leloup et al. (1993, 1995, 2001) and Wang et al. (1998b, 2000a), the main phase of major shearing was between the Oligocene (32 Ma, possibly even latest Eocene at $36 \mathrm{Ma}$ ) and the middle/late Miocene boundary ( $\sim 16 \mathrm{Ma})$. From Fig. 4 , it appears that movement along the Red River Fault has not led to age resetting of the Emeishan Basalts; the youngest reset age is $40 \mathrm{Ma}$.

\subsection{South China fold and thrust belt}

The NE-SW orientated South China fold and thrust belt occurs to the southeast of the Emeishan LIP. Wang et al. (1998a) subdivide the region intro three parallel sub-belts. The timing of folding in both the South China Belt senso stricto and the central South China Fold belt immediately to the northwest cannot be fixed with any precision (middle Mesozoic, Fig. 4). In the northern sub-belt, Oligo-Miocene activity may have taken place which Wang et al. (1998a) link to the reactivation of the Longmen Shan Thrust Belt.

\subsection{Structures within the Emeishan LIP}

The study of Wang et al. (1998a) provides a comprehensive review of the Xianshuihe-Xiaojiang Fault and other faults and associated structures that affect the western Yangtze Platform where the Emeishan LIP is exposed. Activity in the region probably extends back to the Oligocene, with younger activity being particularly intense. Thus, the related deformation post-dates the Emeishan LIP reset events.

\subsection{Summary}

A review of the tectonic phases/structural domains that may have led to the age resetting of the Emeishan Basalts has eliminated several potential causes and focused attention on one, the Longmen Shan Thrust Belt. The timing of activity seems the most probable cause of all four events, although the final suturing of the North and South China Blocks along the Qinling-Dabie suture could have been responsible for the Middle Jurassic event at around $175 \mathrm{Ma}$.

\section{Conclusion}

An apparently complex, and largely post-formational, set of $\mathrm{Ar}-\mathrm{Ar}$ ages obtained from the Permian Emeishan LIP may in fact provide further insights into the tectonism the western Yangtze platform experienced in the Meso- and Cenozoic. The ages can be used to define three and possibly four resetting events at $\sim 175, \sim 142, \sim 98$ and $\sim 42$ Ma. Based on the known timing of regional tectonic events, it is suggested that movements associated with the Longmen Shan Thrust Belt is the likely cause of overprinting, although final collision of the North and South China blocks in the Middle Jurassic may also be implicated as a cause of the older event.

\section{Acknowledgements}

This research was funded by a HKU CRCG grant to JRA and a Stephen S.F. Hui Fund grant to GMT. Ian Metcalfe kindly supplied an electronic version of the terranes and sutures map which with minor modifications we present as part of Fig. 5. Professors C.J.L Wilson and B.C. Burchfiel kindly supplied reprints of their work on the Longmen Shan Thrust Belt. We are grateful for the detailed review by James Lee and to Erchie Wang for directing us to recently published work on the Lhasa-Qiantang block collision and its possible impact on the western Yangtze platform/Dabie mountain area.

\section{Appendix A}

Results of ${ }^{40} \mathrm{Ar} /{ }^{39} \mathrm{Ar}$ incremental heating experiments Ebian-Mt Emei area

\begin{tabular}{|c|c|c|c|c|c|c|c|c|}
\hline$T\left({ }^{\circ} \mathrm{C}\right)$ & cum. ${ }^{39} \mathrm{Ar}_{\mathrm{K}}$ & $\begin{array}{l}\text { Atmos. } \\
(\%)\end{array}$ & ${ }^{36} \mathrm{Ar} /{ }^{39} \mathrm{Ar}$ & ${ }^{37} \mathrm{Ar} /{ }^{39} \mathrm{Ar}$ & ${ }^{38} \mathrm{Ar} /{ }^{39} \mathrm{Ar}$ & ${ }^{40} \mathrm{Ar} /{ }^{39} \mathrm{Ar}$ & ${ }^{40} \mathrm{Ar} /{ }^{36} \mathrm{Ar}$ & $\begin{array}{l}\text { Date } \\
\text { (Ma) }\end{array}$ \\
\hline \multicolumn{9}{|c|}{ EB2-1 Whole Rock ${ }^{\mathrm{a}}$} \\
\hline 550 & 0.016 & 55.787 & $0.72487 \times 10^{-1}$ & 0.47341 & $0.32511 \times 10^{-1}$ & $0.38360 \times 10^{+2}$ & $0.52920 \times 10^{+3}$ & $90.8 \pm 3.8$ \\
\hline 600 & 0.042 & 29.274 & $0.37972 \times 10^{-1}$ & 0.53733 & $0.29573 \times 10^{-1}$ & $0.38221 \times 10^{+2}$ & $0.10065 \times 10^{+4}$ & $142.7 \pm 5.6$ \\
\hline 650 & 0.095 & 25.774 & $0.30872 \times 10^{-1}$ & 0.52676 & $0.24389 \times 10^{-1}$ & $0.35270 \times 10^{+2}$ & $0.11425 \times 10^{+4}$ & $138.3 \pm 1.9$ \\
\hline 700 & 0.173 & 27.511 & $0.33021 \times 10^{-1}$ & 0.50200 & $0.22657 \times 10^{-1}$ & $0.35359 \times 10^{+2}$ & $0.10708 \times 10^{+4}$ & $135.5 \pm 1.7$ \\
\hline 800 & 0.352 & 21.864 & $0.24976 \times 10^{-1}$ & 0.46592 & $0.23410 \times 10^{-1}$ & $0.33624 \times 10^{+2}$ & $0.13463 \times 10^{+4}$ & $138.8 \pm 1.6$ \\
\hline
\end{tabular}


(continued)

\begin{tabular}{|c|c|c|c|c|c|c|c|c|}
\hline$\overline{T\left({ }^{\circ} \mathrm{C}\right)}$ & cum. ${ }^{39} \mathrm{Ar}_{\mathrm{K}}$ & $\begin{array}{l}\text { Atmos. } \\
(\%)\end{array}$ & ${ }^{36} \mathrm{Ar} /{ }^{39} \mathrm{Ar}$ & ${ }^{37} \mathrm{Ar} /{ }^{39} \mathrm{Ar}$ & ${ }^{38} \mathrm{Ar} /{ }^{39} \mathrm{Ar}$ & ${ }^{40} \mathrm{Ar} /{ }^{39} \mathrm{Ar}$ & ${ }^{40} \mathrm{Ar} /{ }^{36} \mathrm{Ar}$ & $\begin{array}{l}\text { Date } \\
\text { (Ma) }\end{array}$ \\
\hline 850 & 0.474 & 19.639 & $0.22084 \times 10^{-1}$ & 0.47559 & $0.29957 \times 10^{-1}$ & $0.33076 \times 10^{+2}$ & $0.14977 \times 10^{+4}$ & $140.3 \pm 1.8$ \\
\hline 950 & 0.669 & 23.360 & $0.28117 \times 10^{-1}$ & 0.78622 & $0.38348 \times 10^{-1}$ & $0.35342 \times 10^{+2}$ & $0.12570 \times 10^{+4}$ & $142.9 \pm 1.6$ \\
\hline 1000 & 0.749 & 36.376 & $0.51156 \times 10^{-1}$ & $0.12274 \times 10^{+1}$ & $0.46127 \times 10^{-1}$ & $0.41331 \times 10^{+2}$ & $0.80794 \times 10^{+3}$ & $139.0 \pm 1.6$ \\
\hline 1050 & 0.821 & 49.149 & $0.86497 \times 10^{-1}$ & $0.15063 \times 10^{+1}$ & $0.59899 \times 10^{-1}$ & $0.51803 \times 10^{+2}$ & $0.59890 \times 10^{+3}$ & $139.3 \pm 1.7$ \\
\hline 1100 & 0.921 & 46.914 & $0.93047 \times 10^{-1}$ & $0.37656 \times 10^{+1}$ & $0.64029 \times 10^{-1}$ & $0.58032 \times 10^{+2}$ & $0.62368 \times 10^{+3}$ & $162.1 \pm 2.0$ \\
\hline 1200 & 1.000 & 82.850 & 0.54436 & $0.22708 \times 10^{+1}$ & 0.15816 & $0.19398 \times 10^{+3}$ & $0.35634 \times 10^{+3}$ & $174.3 \pm 3.8$ \\
\hline \multicolumn{9}{|c|}{ EB3-4B Whole Rock ${ }^{\mathrm{b}}$} \\
\hline 400 & 0.024 & 61.324 & $0.25544 \times 10^{-1}$ & 0.87179 & $0.33604 \times 10^{-1}$ & $0.12230 \times 10^{+2}$ & $0.47879 \times 10^{+3}$ & $25.8 \pm 2.5$ \\
\hline 500 & 0.067 & 34.703 & $0.17961 \times 10^{-1}$ & 0.57948 & $0.29005 \times 10^{-1}$ & $0.15197 \times 10^{+2}$ & $0.84609 \times 10^{+3}$ & $53.6 \pm 1.1$ \\
\hline 550 & 0.108 & 20.679 & $0.12286 \times 10^{-1}$ & 0.43478 & $0.23965 \times 10^{-1}$ & $0.17428 \times 10^{+2}$ & $0.14185 \times 10^{+4}$ & $74.3 \pm 1.2$ \\
\hline 600 & 0.138 & 13.330 & $0.92118 \times 10^{-2}$ & 0.43355 & $0.22521 \times 10^{-1}$ & $0.20205 \times 10^{+2}$ & $0.21933 \times 10^{+4}$ & $93.6 \pm 1.9$ \\
\hline 650 & 0.160 & 14.965 & $0.10861 \times 10^{-1}$ & 0.81649 & $0.23856 \times 10^{-1}$ & $0.21063 \times 10^{+2}$ & $0.19394 \times 10^{+4}$ & $95.7 \pm 1.4$ \\
\hline 800 & 0.361 & 8.917 & $0.64243 \times 10^{-2}$ & 0.24031 & $0.28140 \times 10^{-1}$ & $0.21114 \times 10^{+2}$ & $0.32867 \times 10^{+4}$ & $102.6 \pm 1.8$ \\
\hline 850 & 0.497 & 10.343 & $0.75839 \times 10^{-2}$ & 0.22736 & $0.20311 \times 10^{-1}$ & $0.21531 \times 10^{+2}$ & $0.28390 \times 10^{+4}$ & $102.9 \pm 1.1$ \\
\hline 900 & 0.612 & 10.398 & $0.76009 \times 10^{-2}$ & 0.40984 & $0.20990 \times 10^{-1}$ & $0.21332 \times 10^{+2}$ & $0.28065 \times 10^{+4}$ & $102.0 \pm 1.1$ \\
\hline 950 & 0.738 & 10.654 & $0.76691 \times 10^{-2}$ & 0.63485 & $0.23559 \times 10^{-1}$ & $0.20850 \times 10^{+2}$ & $0.27187 \times 10^{+4}$ & $99.4 \pm 1.1$ \\
\hline 1000 & 0.833 & 18.395 & $0.14678 \times 10^{-1}$ & $0.14309 \times 10^{+1}$ & $0.33638 \times 10^{-1}$ & $0.23022 \times 10^{+2}$ & $0.15685 \times 10^{+4}$ & $100.3 \pm 1.1$ \\
\hline 1050 & 0.886 & 43.208 & $0.50066 \times 10^{-1}$ & $0.33251 \times 10^{+1}$ & $0.76670 \times 10^{-1}$ & $0.33689 \times 10^{+2}$ & $0.67289 \times 10^{+3}$ & $102.3 \pm 1.3$ \\
\hline 1100 & 0.946 & 43.535 & $0.60643 \times 10^{-1}$ & $0.61432 \times 10^{+1}$ & $0.98498 \times 10^{-1}$ & $0.40128 \times 10^{+2}$ & $0.66170 \times 10^{+3}$ & $120.8 \pm 1.5$ \\
\hline 1150 & 0.982 & 60.058 & 0.13136 & $0.22497 \times 10^{+1}$ & $0.91166 \times 10^{-1}$ & $0.64380 \times 10^{+2}$ & $0.49009 \times 10^{+3}$ & $136.1 \pm 1.8$ \\
\hline 1200 & 1.000 & 81.473 & 0.38268 & $0.12135 \times 10^{+1}$ & 0.14660 & $0.13871 \times 10^{+3}$ & $0.36248 \times 10^{+3}$ & $136.0 \pm 3.2$ \\
\hline \multicolumn{9}{|c|}{ EB5-5a Whole Rock ${ }^{\mathrm{c}}$} \\
\hline 400 & 0.012 & 3.173 & $0.12044 \times 10^{-2}$ & 0.44458 & $0.32825 \times 10^{-1}$ & $0.10189 \times 10^{+2}$ & $0.84597 \times 10^{+4}$ & $53.3 \pm 4.5$ \\
\hline 500 & 0.083 & 30.073 & $0.13910 \times 10^{-1}$ & 0.31860 & $0.35382 \times 10^{-1}$ & $0.13617 \times 10^{+2}$ & $0.97895 \times 10^{+3}$ & $51.5 \pm 2.1$ \\
\hline 550 & 0.132 & 23.775 & $0.12430 \times 10^{-1}$ & 0.25048 & $0.29661 \times 10^{-1}$ & $0.15398 \times 10^{+2}$ & $0.12388 \times 10^{+4}$ & $63.2 \pm 1.4$ \\
\hline 600 & 0.168 & 9.242 & $0.57364 \times 10^{-2}$ & 0.25931 & $0.27528 \times 10^{-1}$ & $0.18158 \times 10^{+2}$ & $0.31653 \times 10^{+4}$ & $88.2 \pm 2.1$ \\
\hline 650 & 0.201 & 13.154 & $0.88831 \times 10^{-2}$ & 0.29776 & $0.25471 \times 10^{-1}$ & $0.19813 \times 10^{+2}$ & $0.22304 \times 10^{+4}$ & $92.0 \pm 1.6$ \\
\hline 700 & 0.235 & 11.782 & $0.83378 \times 10^{-2}$ & 0.23838 & $0.23581 \times 10^{-1}$ & $0.20787 \times 10^{+2}$ & $0.24932 \times 10^{+4}$ & $97.9 \pm 1.9$ \\
\hline 900 & 0.566 & 9.949 & $0.67242 \times 10^{-2}$ & 0.22479 & $0.21728 \times 10^{-1}$ & $0.19830 \times 10^{+2}$ & $0.29491 \times 10^{+4}$ & $95.4 \pm 1.0$ \\
\hline 950 & 0.676 & 9.468 & $0.64962 \times 10^{-2}$ & 0.30381 & $0.25781 \times 10^{-1}$ & $0.20063 \times 10^{+2}$ & $0.30884 \times 10^{+4}$ & $97.0 \pm 1.1$ \\
\hline 1000 & 0.780 & 13.020 & $0.96255 \times 10^{-2}$ & 0.54571 & $0.32514 \times 10^{-1}$ & $0.21558 \times 10^{+2}$ & $0.22397 \times 10^{+4}$ & $100.1 \pm 1.1$ \\
\hline 1050 & 0.838 & 31.232 & $0.29127 \times 10^{-1}$ & 0.89500 & $0.45854 \times 10^{-1}$ & $0.27371 \times 10^{+2}$ & $0.93971 \times 10^{+3}$ & $100.5 \pm 1.2$ \\
\hline 1100 & 0.924 & 28.031 & $0.31457 \times 10^{-1}$ & $0.21891 \times 10^{+1}$ & $0.69089 \times 10^{-1}$ & $0.32603 \times 10^{+2}$ & $0.10364 \times 10^{+4}$ & $124.6 \pm 1.4$ \\
\hline 1150 & 0.972 & 52.839 & $0.85464 \times 10^{-1}$ & $0.22429 \times 10^{+1}$ & $0.92958 \times 10^{-1}$ & $0.47504 \times 10^{+2}$ & $0.55584 \times 10^{+3}$ & $119.2 \pm 1.8$ \\
\hline 1200 & 1.000 & 61.012 & 0.15859 & $0.16171 \times 10^{+1}$ & 0.11425 & $0.76639 \times 10^{+2}$ & $0.48326 \times 10^{+3}$ & $157.2 \pm 3.8$ \\
\hline \multicolumn{9}{|c|}{ EB6-3 Whole Rock ${ }^{\mathrm{d}}$} \\
\hline 400 & 0.109 & 21.035 & $0.46286 \times 10^{-2}$ & 0.15200 & $0.26649 \times 10^{-1}$ & $0.64766 \times 10^{+1}$ & $0.13993 \times 10^{+4}$ & $27.8 \pm 2.2$ \\
\hline 500 & 0.157 & 20.288 & $0.64303 \times 10^{-2}$ & 0.14991 & $0.20475 \times 10^{-1}$ & $0.93388 \times 10^{+1}$ & $0.14523 \times 10^{+4}$ & $40.3 \pm 1.0$ \\
\hline 580 & 0.255 & 10.494 & $0.38029 \times 10^{-2}$ & 0.11739 & $0.19263 \times 10^{-1}$ & $0.10653 \times 10^{+2}$ & $0.28012 \times 10^{+4}$ & $51.5 \pm 0.8$ \\
\hline 660 & 0.323 & 7.532 & $0.35315 \times 10^{-2}$ & 0.13835 & $0.17185 \times 10^{-1}$ & $0.13746 \times 10^{+2}$ & $0.38924 \times 10^{+4}$ & $68.4 \pm 0.9$ \\
\hline 720 & 0.376 & 6.120 & $0.34554 \times 10^{-2}$ & $0.98781 \times 10^{-1}$ & $0.17147 \times 10^{-1}$ & $0.16592 \times 10^{+2}$ & $0.48017 \times 10^{+4}$ & $83.5 \pm 1.0$ \\
\hline 780 & 0.447 & 7.073 & $0.42460 \times 10^{-2}$ & $0.74769 \times 10^{-1}$ & $0.19615 \times 10^{-1}$ & $0.17688 \times 10^{+2}$ & $0.41659 \times 10^{+4}$ & $88.0 \pm 1.2$ \\
\hline 840 & 0.571 & 5.393 & $0.31274 \times 10^{-2}$ & $0.83474 \times 10^{-1}$ & $0.17403 \times 10^{-1}$ & $0.17048 \times 10^{+2}$ & $0.54511 \times 10^{+4}$ & $86.4 \pm 1.0$ \\
\hline 900 & 0.705 & 6.480 & $0.34882 \times 10^{-2}$ & 0.15404 & $0.18126 \times 10^{-1}$ & $0.15756 \times 10^{+2}$ & $0.45171 \times 10^{+4}$ & $79.1 \pm 0.8$ \\
\hline 980 & 0.844 & 11.070 & $0.55767 \times 10^{-2}$ & 0.35490 & $0.22342 \times 10^{-1}$ & $0.14673 \times 10^{+2}$ & $0.26312 \times 10^{+4}$ & $70.2 \pm 0.7$ \\
\hline 1040 & 0.905 & 31.988 & $0.20688 \times 10^{-1}$ & 0.64349 & $0.37065 \times 10^{-1}$ & $0.18988 \times 10^{+2}$ & $0.91786 \times 10^{+3}$ & $69.5 \pm 0.9$ \\
\hline 1100 & 0.948 & 43.991 & $0.41604 \times 10^{-1}$ & $0.13540 \times 10^{+1}$ & $0.75452 \times 10^{-1}$ & $0.27743 \times 10^{+2}$ & $0.66684 \times 10^{+3}$ & $83.4 \pm 1.3$ \\
\hline 1150 & 0.983 & 45.594 & $0.70476 \times 10^{-1}$ & $0.18181 \times 10^{+1}$ & 0.10424 & $0.45404 \times 10^{+2}$ & $0.64426 \times 10^{+3}$ & $130.9 \pm 1.6$ \\
\hline 1200 & 1.000 & 56.943 & 0.15509 & $0.14280 \times 10^{+1}$ & 0.11833 & $0.80322 \times 10^{+2}$ & $0.51790 \times 10^{+3}$ & $180.7 \pm 2.2$ \\
\hline \multicolumn{9}{|c|}{ EB7-2 Whole Rock ${ }^{\mathrm{e}}$} \\
\hline 400 & 0.004 & 57.233 & $0.45299 \times 10^{-1}$ & 0.42071 & $0.92447 \times 10^{-1}$ & $0.23362 \times 10^{+2}$ & $0.51572 \times 10^{+3}$ & $54.0 \pm 4.0$ \\
\hline 500 & 0.024 & 56.058 & $0.52136 \times 10^{-1}$ & 0.31733 & $0.58824 \times 10^{-1}$ & $0.27469 \times 10^{+2}$ & $0.52687 \times 10^{+3}$ & $65.1 \pm 2.1$ \\
\hline 560 & 0.047 & 37.544 & $0.38447 \times 10^{-1}$ & 0.19140 & $0.38048 \times 10^{-1}$ & $0.30251 \times 10^{+2}$ & $0.78682 \times 10^{+3}$ & $100.8 \pm 1.7$ \\
\hline 620 & 0.078 & 25.692 & $0.24263 \times 10^{-1}$ & 0.19158 & $0.33210 \times 10^{-1}$ & $0.27879 \times 10^{+2}$ & $0.11490 \times 10^{+4}$ & $110.3 \pm 1.7$ \\
\hline 680 & 0.114 & 14.677 & $0.14968 \times 10^{-1}$ & 0.15938 & $0.25340 \times 10^{-1}$ & $0.30084 \times 10^{+2}$ & $0.20098 \times 10^{+4}$ & $135.7 \pm 1.6$ \\
\hline 740 & 0.159 & 9.880 & $0.10494 \times 10^{-1}$ & 0.11896 & $0.20128 \times 10^{-1}$ & $0.31324 \times 10^{+2}$ & $0.29849 \times 10^{+4}$ & $148.7 \pm 1.6$ \\
\hline 800 & 0.235 & 9.781 & $0.10180 \times 10^{-1}$ & $0.94032 \times 10^{-1}$ & $0.18726 \times 10^{-1}$ & $0.30712 \times 10^{+2}$ & $0.30168 \times 10^{+4}$ & $146.0 \pm 1.5$ \\
\hline 860 & 0.367 & 6.603 & $0.68519 \times 10^{-2}$ & $0.85574 \times 10^{-1}$ & $0.18127 \times 10^{-1}$ & $0.30597 \times 10^{+2}$ & $0.44655 \times 10^{+4}$ & $150.4 \pm 1.5$ \\
\hline 920 & 0.510 & 5.378 & $0.54080 \times 10^{-2}$ & 0.11140 & $0.21787 \times 10^{-1}$ & $0.29589 \times 10^{+2}$ & $0.54714 \times 10^{+4}$ & $147.5 \pm 1.5$ \\
\hline
\end{tabular}


(continued)




(continued)

\begin{tabular}{|c|c|c|c|c|c|c|c|c|}
\hline$T\left({ }^{\circ} \mathrm{C}\right)$ & cum. ${ }^{39} \mathrm{Ar}_{\mathrm{K}}$ & $\begin{array}{l}\text { Atmos. } \\
(\%)\end{array}$ & ${ }^{36} \mathrm{Ar} /{ }^{39} \mathrm{Ar}$ & ${ }^{37} \mathrm{Ar} /{ }^{39} \mathrm{Ar}$ & ${ }^{38} \mathrm{Ar} /{ }^{39} \mathrm{Ar}$ & ${ }^{40} \mathrm{Ar} /{ }^{39} \mathrm{Ar}$ & ${ }^{40} \mathrm{Ar} /{ }^{36} \mathrm{Ar}$ & $\begin{array}{l}\text { Date } \\
(\mathrm{Ma})\end{array}$ \\
\hline 1080 & 0.941 & 31.476 & $0.19376 \times 10^{-1}$ & $0.10359 \times 10^{+1}$ & $0.39362 \times 10^{-1}$ & $0.17971 \times 10^{+2}$ & $0.92748 \times 10^{+3}$ & $66.4 \pm 0.7$ \\
\hline 1120 & 0.973 & 54.974 & $0.60710 \times 10^{-1}$ & $0.16195 \times 10^{+1}$ & $0.55978 \times 10^{-1}$ & $0.32440 \times 10^{+2}$ & $0.53434 \times 10^{+3}$ & $78.5 \pm 1.2$ \\
\hline 1160 & 0.980 & 85.607 & 0.34904 & $0.13267 \times 10^{+1}$ & 0.12160 & $0.12039 \times 10^{+3}$ & $0.34493 \times 10^{+3}$ & $92.8 \pm 3.7$ \\
\hline 1200 & 1.000 & 63.095 & 0.14258 & $0.17816 \times 10^{+1}$ & $0.81082 \times 10^{-1}$ & $0.66591 \times 10^{+2}$ & $0.46705 \times 10^{+3}$ & $130.3 \pm 2.7$ \\
\hline \multicolumn{9}{|c|}{ EM26-5a Whole Rock ${ }^{\mathrm{j}}$} \\
\hline 400 & 0.004 & 28.929 & $0.39620 \times 10^{-1}$ & 0.22527 & $0.81301 \times 10^{-4}$ & $0.40441 \times 10^{+2}$ & $0.10207 \times 10^{+4}$ & $151.3 \pm 29.6$ \\
\hline 500 & 0.152 & 14.313 & $0.17181 \times 10^{-1}$ & 0.40608 & $0.26308 \times 10^{-1}$ & $0.35285 \times 10^{+2}$ & $0.20537 \times 10^{+4}$ & $158.8 \pm 2.0$ \\
\hline 600 & 0.414 & 10.213 & $0.12936 \times 10^{-1}$ & 0.31771 & $0.29338 \times 10^{-1}$ & $0.37225 \times 10^{+2}$ & $0.28775 \times 10^{+4}$ & $174.8 \pm 2.6$ \\
\hline 660 & 0.568 & 15.475 & $0.17727 \times 10^{-1}$ & 0.48431 & $0.39571 \times 10^{-1}$ & $0.33644 \times 10^{+2}$ & $0.18979 \times 10^{+4}$ & $149.8 \pm 2.9$ \\
\hline 720 & 0.658 & 10.634 & $0.12452 \times 10^{-1}$ & 0.43543 & $0.34198 \times 10^{-1}$ & $0.34321 \times 10^{+2}$ & $0.27563 \times 10^{+4}$ & $161.0 \pm 2.2$ \\
\hline 780 & 0.705 & 27.042 & $0.31129 \times 10^{-1}$ & 0.38297 & $0.43125 \times 10^{-1}$ & $0.33938 \times 10^{+2}$ & $0.10902 \times 10^{+4}$ & $131.1 \pm 3.8$ \\
\hline 840 & 0.737 & 33.815 & $0.43355 \times 10^{-1}$ & 0.46440 & $0.62335 \times 10^{-1}$ & $0.37812 \times 10^{+2}$ & $0.87215 \times 10^{+3}$ & $132.4 \pm 4.4$ \\
\hline 900 & 0.765 & 61.006 & $0.93261 \times 10^{-1}$ & 0.99067 & 0.10408 & $0.45080 \times 10^{+2}$ & $0.48337 \times 10^{+3}$ & $94.1 \pm 4.3$ \\
\hline 950 & 0.787 & 55.102 & 0.11262 & $0.20840 \times 10^{+1}$ & 0.14785 & $0.60140 \times 10^{+2}$ & $0.53400 \times 10^{+3}$ & $142.7 \pm 6.9$ \\
\hline 1040 & 0.843 & 49.818 & 0.14055 & $0.47251 \times 10^{+1}$ & 0.16489 & $0.82682 \times 10^{+2}$ & $0.58827 \times 10^{+3}$ & $215.2 \pm 5.2$ \\
\hline 1080 & 0.868 & 77.304 & 0.34395 & $0.70565 \times 10^{+1}$ & 0.23404 & $0.13082 \times 10^{+3}$ & $0.38034 \times 10^{+3}$ & $156.8 \pm 6.1$ \\
\hline 1120 & 0.892 & 56.971 & 0.29621 & $0.24882 \times 10^{+1}$ & 0.21391 & $0.15334 \times 10^{+3}$ & $0.51767 \times 10^{+3}$ & $330.7 \pm 4.9$ \\
\hline 1160 & 0.948 & 64.916 & 0.24610 & $0.15543 \times 10^{+1}$ & 0.17094 & $0.11187 \times 10^{+3}$ & $0.45459 \times 10^{+3}$ & $203.8 \pm 2.5$ \\
\hline 1200 & 1.000 & 60.101 & 0.28530 & $0.13792 \times 10^{+1}$ & 0.21800 & $0.14013 \times 10^{+3}$ & $0.49117 \times 10^{+3}$ & $283.8 \pm 3.2$ \\
\hline \multicolumn{9}{|c|}{ EM27-1 Whole Rock ${ }^{\mathrm{k}}$} \\
\hline 400 & 0.029 & 27.107 & $0.77817 \times 10^{-2}$ & 0.18861 & $0.18075 \times 10^{-1}$ & $0.84594 \times 10^{+1}$ & $0.10871 \times 10^{+4}$ & $33.5 \pm 0.9$ \\
\hline 500 & 0.154 & 12.967 & $0.52120 \times 10^{-2}$ & 0.18651 & $0.17470 \times 10^{-1}$ & $0.11798 \times 10^{+2}$ & $0.22636 \times 10^{+4}$ & $55.4 \pm 0.8$ \\
\hline 600 & 0.277 & 8.214 & $0.45066 \times 10^{-2}$ & 0.13735 & $0.15845 \times 10^{-1}$ & $0.16115 \times 10^{+2}$ & $0.35759 \times 10^{+4}$ & $79.3 \pm 1.0$ \\
\hline 660 & 0.343 & 9.664 & $0.57225 \times 10^{-2}$ & 0.16880 & $0.16819 \times 10^{-1}$ & $0.17395 \times 10^{+2}$ & $0.30398 \times 10^{+4}$ & $84.2 \pm 1.0$ \\
\hline 720 & 0.390 & 7.340 & $0.48923 \times 10^{-2}$ & 0.17453 & $0.18457 \times 10^{-1}$ & $0.19546 \times 10^{+2}$ & $0.39953 \times 10^{+4}$ & $96.7 \pm 1.1$ \\
\hline 780 & 0.441 & 3.876 & $0.27704 \times 10^{-2}$ & 0.16446 & $0.16871 \times 10^{-1}$ & $0.20829 \times 10^{+2}$ & $0.75184 \times 10^{+4}$ & $106.6 \pm 1.3$ \\
\hline 840 & 0.526 & 7.154 & $0.49888 \times 10^{-2}$ & 0.15921 & $0.18253 \times 10^{-1}$ & $0.20468 \times 10^{+2}$ & $0.41027 \times 10^{+4}$ & $101.4 \pm 1.1$ \\
\hline 900 & 0.633 & 9.897 & $0.63440 \times 10^{-2}$ & 0.24773 & $0.20769 \times 10^{-1}$ & $0.18782 \times 10^{+2}$ & $0.29606 \times 10^{+4}$ & $90.5 \pm 1.0$ \\
\hline 950 & 0.723 & 15.043 & $0.99103 \times 10^{-2}$ & 0.33947 & $0.23585 \times 10^{-1}$ & $0.19327 \times 10^{+2}$ & $0.19502 \times 10^{+4}$ & $87.9 \pm 1.0$ \\
\hline 1000 & 0.814 & 25.806 & $0.16868 \times 10^{-1}$ & 0.44184 & $0.27094 \times 10^{-1}$ & $0.19215 \times 10^{+2}$ & $0.11391 \times 10^{+4}$ & $76.6 \pm 0.8$ \\
\hline 1160 & 0.969 & 57.074 & 0.10881 & 0.75446 & $0.77747 \times 10^{-1}$ & $0.56266 \times 10^{+2}$ & $0.51710 \times 10^{+3}$ & $128.0 \pm 2.0$ \\
\hline 1200 & 1.000 & 67.379 & 0.17599 & 0.54307 & $0.87302 \times 10^{-1}$ & $0.77152 \times 10^{+2}$ & $0.43838 \times 10^{+3}$ & $133.2 \pm 2.8$ \\
\hline \multicolumn{9}{|c|}{ EM31-2b Whole Rock ${ }^{1}$} \\
\hline 400 & 0.039 & 25.575 & $0.35356 \times 10^{-1}$ & 0.28392 & $0.50590 \times 10^{-1}$ & $0.40797 \times 10^{+2}$ & $0.11539 \times 10^{+4}$ & $159.5 \pm 3.0$ \\
\hline 500 & 0.364 & 16.643 & $0.23034 \times 10^{-1}$ & 0.19886 & $0.42442 \times 10^{-1}$ & $0.40836 \times 10^{+2}$ & $0.17729 \times 10^{+4}$ & $177.8 \pm 2.9$ \\
\hline 600 & 0.632 & 11.581 & $0.17092 \times 10^{-1}$ & 0.11185 & $0.34859 \times 10^{-1}$ & $0.43568 \times 10^{+2}$ & $0.25490 \times 10^{+4}$ & $200.0 \pm 2.6$ \\
\hline 660 & 0.747 & 10.605 & $0.14875 \times 10^{-1}$ & 0.14518 & $0.44178 \times 10^{-1}$ & $0.41372 \times 10^{+2}$ & $0.27814 \times 10^{+4}$ & $192.4 \pm 2.7$ \\
\hline 720 & 0.791 & 36.141 & $0.42652 \times 10^{-1}$ & 0.21813 & $0.66008 \times 10^{-1}$ & $0.34857 \times 10^{+2}$ & $0.81724 \times 10^{+3}$ & $118.2 \pm 4.1$ \\
\hline 780 & 0.812 & 46.527 & $0.51229 \times 10^{-1}$ & 0.34105 & $0.90648 \times 10^{-1}$ & $0.32510 \times 10^{+2}$ & $0.63460 \times 10^{+3}$ & $93.0 \pm 10.6$ \\
\hline 840 & 0.825 & 76.110 & 0.11367 & 0.59464 & 0.12896 & $0.44104 \times 10^{+2}$ & $0.38799 \times 10^{+3}$ & $57.0 \pm 16.2$ \\
\hline 900 & 0.836 & 65.596 & 0.16737 & $0.18510 \times 10^{+1}$ & 0.26413 & $0.75215 \times 10^{+2}$ & $0.44938 \times 10^{+3}$ & $136.9 \pm 13.8$ \\
\hline 950 & 0.849 & 58.534 & 0.21187 & $0.41032 \times 10^{+1}$ & 0.32582 & $0.10646 \times 10^{+3}$ & $0.50248 \times 10^{+3}$ & $228.1 \pm 22.7$ \\
\hline 1000 & 0.861 & 73.365 & 0.32214 & $0.43219 \times 10^{+1}$ & 0.31947 & $0.12933 \times 10^{+3}$ & $0.40149 \times 10^{+3}$ & $180.4 \pm 26.2$ \\
\hline 1040 & 0.879 & 71.234 & 0.35470 & $0.80274 \times 10^{+1}$ & 0.33013 & $0.14632 \times 10^{+3}$ & $0.41251 \times 10^{+3}$ & $218.6 \pm 11.5$ \\
\hline 1080 & 0.901 & 55.380 & 0.33161 & $0.57913 \times 10^{+1}$ & 0.33540 & $0.17618 \times 10^{+3}$ & $0.53129 \times 10^{+3}$ & $388.4 \pm 7.9$ \\
\hline 1120 & 0.918 & 82.653 & 0.83551 & $0.36137 \times 10^{+1}$ & 0.43492 & $0.29841 \times 10^{+3}$ & $0.35716 \times 10^{+3}$ & $264.6 \pm 17.5$ \\
\hline 1160 & 0.969 & 62.626 & 0.36227 & $0.32504 \times 10^{+1}$ & 0.36220 & $0.17057 \times 10^{+3}$ & $0.47084 \times 10^{+3}$ & $320.6 \pm 6.1$ \\
\hline 1200 & 1.000 & 77.465 & 0.84208 & $0.31334 \times 10^{+1}$ & 0.58363 & $0.32094 \times 10^{+3}$ & $0.38113 \times 10^{+3}$ & $359.7 \pm 6.1$ \\
\hline \multicolumn{9}{|c|}{ EM34-3 Whole Rock ${ }^{\mathrm{m}}$} \\
\hline 400 & 0.017 & 11.575 & $0.16550 \times 10^{-1}$ & 0.56872 & $0.48745 \times 10^{-1}$ & $0.41909 \times 10^{+2}$ & $0.25323 \times 10^{+4}$ & $192.8 \pm 10.1$ \\
\hline 500 & 0.237 & 19.046 & $0.20330 \times 10^{-1}$ & 0.31229 & $0.72969 \times 10^{-1}$ & $0.31447 \times 10^{+2}$ & $0.15468 \times 10^{+4}$ & $134.6 \pm 10.9$ \\
\hline 600 & 0.472 & 9.153 & $0.10487 \times 10^{-1}$ & 0.17681 & $0.44282 \times 10^{-1}$ & $0.33742 \times 10^{+2}$ & $0.32174 \times 10^{+4}$ & $160.9 \pm 3.8$ \\
\hline 660 & 0.561 & 15.546 & $0.15898 \times 10^{-1}$ & 0.27163 & $0.61193 \times 10^{-1}$ & $0.30116 \times 10^{+2}$ & $0.18944 \times 10^{+4}$ & $134.5 \pm 3.0$ \\
\hline 720 & 0.601 & 41.593 & $0.36783 \times 10^{-1}$ & 0.28623 & $0.75860 \times 10^{-1}$ & $0.26109 \times 10^{+2}$ & $0.70982 \times 10^{+3}$ & $81.8 \pm 4.6$ \\
\hline 780 & 0.627 & 85.431 & $0.62870 \times 10^{-1}$ & 0.31958 & 0.12366 & $0.21747 \times 10^{+2}$ & $0.34590 \times 10^{+3}$ & $17.3 \pm 7.1$ \\
\hline 900 & 0.657 & 75.424 & $0.98135 \times 10^{-1}$ & $0.12070 \times 10^{+1}$ & 0.23935 & $0.38356 \times 10^{+2}$ & $0.39085 \times 10^{+3}$ & $51.1 \pm 5.1$ \\
\hline 1000 & 0.696 & 72.613 & 0.16130 & $0.35738 \times 10^{+1}$ & 0.26393 & $0.65301 \times 10^{+2}$ & $0.40483 \times 10^{+3}$ & $95.8 \pm 3.2$ \\
\hline 1060 & 0.758 & 49.111 & 0.13616 & $0.47333 \times 10^{+1}$ & 0.23763 & $0.81227 \times 10^{+2}$ & $0.59657 \times 10^{+3}$ & $214.4 \pm 3.8$ \\
\hline 1140 & 0.864 & 56.568 & 0.14124 & $0.15305 \times 10^{+1}$ & 0.15869 & $0.73603 \times 10^{+2}$ & $0.52114 \times 10^{+3}$ & $167.7 \pm 3.1$ \\
\hline 1200 & 1.000 & 57.194 & 0.16124 & $0.10549 \times 10^{+1}$ & 0.14813 & $0.83198 \times 10^{+2}$ & $0.51598 \times 10^{+3}$ & $185.8 \pm 2.3$ \\
\hline
\end{tabular}


(continued)

\begin{tabular}{|c|c|c|c|c|c|c|c|c|}
\hline$\overline{T\left({ }^{\circ} \mathrm{C}\right)}$ & cum. ${ }^{39} \mathrm{Ar}_{\mathrm{K}}$ & $\begin{array}{l}\text { Atmos. } \\
(\%)\end{array}$ & ${ }^{36} \mathrm{Ar} /{ }^{39} \mathrm{Ar}$ & ${ }^{37} \mathrm{Ar} /{ }^{39} \mathrm{Ar}$ & ${ }^{38} \mathrm{Ar} /{ }^{39} \mathrm{Ar}$ & ${ }^{40} \mathrm{Ar} /{ }^{39} \mathrm{Ar}$ & ${ }^{40} \mathrm{Ar} /{ }^{36} \mathrm{Ar}$ & $\begin{array}{l}\text { Date } \\
\text { (Ma) }\end{array}$ \\
\hline
\end{tabular}

XC11-5 Whole Rock ${ }^{\mathrm{n}}$

$\begin{array}{ll}600 & 0.107 \\ 660 & 0.267 \\ 720 & 0.318 \\ 780 & 0.360 \\ 840 & 0.437 \\ 900 & 0.542 \\ 950 & 0.628 \\ 1000 & 0.717 \\ 1040 & 0.774 \\ 1080 & 0.816 \\ 1120 & 0.883 \\ 1160 & 0.972 \\ 1200 & 1.000\end{array}$

XC12-2 Whole Rock ${ }^{\circ}$

$400 \quad 0.039$

$500 \quad 0.078$

$600 \quad 0.147$

$660 \quad 0.215$

$720 \quad 0.252$

$780 \quad 0.307$

$840 \quad 0.418$

$900 \quad 0.509$

$950 \quad 0.586$

$1000 \quad 0.638$

$1040 \quad 0.670$

$1080 \quad 0.703$

$1120 \quad 0.761$

$1160 \quad 0.898$

$1200 \quad 1.000$

XC2-3a Whole Rock ${ }^{\mathrm{p}}$

$\begin{array}{ll}500 & 0.017 \\ 600 & 0.064 \\ 660 & 0.101 \\ 720 & 0.163 \\ 780 & 0.237 \\ 840 & 0.332 \\ 900 & 0.446 \\ 950 & 0.602 \\ 1000 & 0.733 \\ 1040 & 0.793 \\ 1080 & 0.924 \\ 1120 & 0.962 \\ 1160 & 0.991 \\ 1200 & 1.000\end{array}$

XC3-3 Whole Rock ${ }^{\mathrm{q}}$

$400 \quad 0.014$

$500 \quad 0.070$

$600 \quad 0.131$

$660 \quad 0.181$

$\begin{array}{ll}720 & 0.230\end{array}$

$780 \quad 0.313$

$840 \quad 0.452$

$950 \quad 0.631$

$1000 \quad 0.755$

$1040 \quad 0.837$

$1080 \quad 0.923$

$1120 \quad 0.951$

$1160 \quad 0.991$

$1200 \quad 1.000$

XC4-3 Whole Rock

$400 \quad 0.034$

$500 \quad 0.081$

$600 \quad 0.136$

$660 \quad 0.198$

$720 \quad 0.284$

$\begin{array}{rl}25.092 & 0.14867 \times 10^{-1} \\ 7.778 & 0.95830 \times 10^{-2} \\ 11.376 & 0.12919 \times 10^{-1} \\ 12.832 & 0.13740 \times 10^{-1} \\ 15.195 & 0.15746 \times 10^{-1} \\ 23.009 & 0.23831 \times 10^{-1} \\ 29.494 & 0.30681 \times 10^{-1} \\ 33.934 & 0.37329 \times 10^{-1} \\ 38.241 & 0.52251 \times 10^{-1} \\ 41.699 & 0.77597 \times 10^{-1} \\ 47.226 & 0.82279 \times 10^{-1} \\ 41.790 & 0.71679 \times 10^{-1} \\ 68.641 & 0.24804\end{array}$

32.305

20.977

22.390

24.981

22.147

16.892

16.079

23.137

27.722

45.035

61.084

63.356

57.496

41.988

52.677

53.660

49.644

38.025

20.784

16.982

14.142

12.009

13.203

21.780

35.742

38.495

56.185

46.956

62.319

33.747

39.424

34.829

28.764

24.205

20.663

11.730

17.751

37.904

33.614

47.376

58.879

56.008

76.718

37.502

15.615

15.030

13.136

10.843

0.33409

$0.15724 \times 10^{-1}$ $0.19074 \times 10^{-1}$ $0.17521 \times 10^{-1}$ $0.14160 \times 10^{-1}$ $0.11740 \times 10^{-1}$ $0.92537 \times 10^{-2}$ $0.47951 \times 10^{-2}$ $0.77409 \times 10^{-2}$ $0.21585 \times 10^{-1}$ $0.25590 \times 10^{-1}$ $0.48924 \times 10^{-1}$ 0.10791

0.11092

0.50216

$0.27954 \times 10^{-}$ $0.99331 \times 10^{-2}$ $0.80735 \times 10^{-2}$ $0.62956 \times 10^{-2}$

$\begin{array}{ll}0.16106 & 0.38163 \times 10^{-1} \\ 0.73028 \times 10^{-1} & 0.22807 \times 10^{-1} \\ 0.98562 \times 10^{-1} & 0.25968 \times 10^{-1} \\ 0.12269 & 0.27162 \times 10^{-1} \\ 0.12451 & 0.29020 \times 10^{-1} \\ 0.24767 & 0.33971 \times 10^{-1} \\ 0.35979 & 0.41027 \times 10^{-1} \\ 0.48493 & 0.54980 \times 10^{-1} \\ 0.78626 & 0.91791 \times 10^{-1} \\ 0.10027 \times 10^{+1} & 0.14072 \\ 0.10936 \times 10^{+1} & 0.13983 \\ 0.84568 & 0.14173 \\ 0.69563 & 0.22797 \\ & \\ 0.53969 & 0.12133 \\ 0.44129 & 0.47502 \times 10^{-1} \\ 0.24648 & 0.36122 \times 10^{-1} \\ 0.35541 & 0.61217 \times 10^{-1} \\ 0.30021 & 0.52044 \times 10^{-1} \\ 0.20302 & 0.41410 \times 10^{-1} \\ 0.17866 & 0.32847 \times 10^{-1} \\ 0.48266 & 0.58894 \times 10^{-1} \\ 0.78703 & 0.77396 \times 10^{-1} \\ 0.20387 \times 10^{+1} & 0.12676 \\ 0.30654 \times 10^{+1} & 0.21735 \\ 0.15863 \times 10^{+1} & 0.23298 \\ 0.76496 & 0.16671 \\ 0.49787 & 0.13507 \\ 0.41060 & 0.17107\end{array}$

$0.49151 \times 10^{-1}$ $0.41179 \times 10^{-1}$ $0.27070 \times 10^{-1}$ $0.22728 \times 10^{-1}$ $0.21130 \times 10^{-1}$ $0.19419 \times 10^{-1}$ $0.22446 \times 10^{-1}$ $0.23193 \times 10^{-1}$ $0.26662 \times 10^{-1}$ $0.35709 \times 10^{-1}$ $0.41412 \times 10^{-1}$ $0.67366 \times 10^{-1}$ 0.10810

0.18036 $0.70902 \times 10^{-2}$
$0.17489 \times 10^{+2}$ $0.36365 \times 10^{+2}$ $0.33520 \times 10^{+2}$ $0.31597 \times 10^{+2}$ $0.30589 \times 10^{+2}$ $0.30552 \times 10^{+2}$ $0.30675 \times 10^{+2}$ $0.32428 \times 10^{+2}$ $0.40250 \times 10^{+2}$ $0.54836 \times 10^{+2}$ $0.51338 \times 10^{+2}$ $0.50562 \times 10^{+2}$ $0.10674 \times 10^{+3}$

$0.32191 \times 10^{+2}$ $0.31142 \times 10^{+2}$ $0.35257 \times 10^{+2}$ $0.36692 \times 10^{+2}$ $0.33095 \times 10^{+2}$ $0.31501 \times 10^{+2}$ $0.31848 \times 10^{+2}$ $0.34205 \times 10^{+2}$ $0.38528 \times 10^{+2}$ $0.49084 \times 10^{+2}$ $0.68629 \times 10^{+2}$ $0.77894 \times 10^{+2}$ $0.68445 \times 10^{+2}$ $0.53002 \times 10^{+2}$ $0.70636 \times 10^{+2}$

$0.13397 \times 10^{+2}$ $0.20029 \times 10^{+2}$ $0.20366 \times 10^{+2}$ $0.18779 \times 10^{+2}$ $0.17549 \times 10^{+2}$ $0.16542 \times 10^{+2}$ $0.16461 \times 10^{+2}$ $0.16390 \times 10^{+2}$ $0.18054 \times 10^{+2}$ $0.21918 \times 10^{+2}$ $0.23113 \times 10^{+2}$ $0.39364 \times 10^{+2}$ $0.60147 \times 10^{+2}$ $0.15828 \times 10^{+3}$

$0.13693 \times 10^{+2}$ $0.14240 \times 10^{+2}$ $0.14819 \times 10^{+2}$ $0.14482 \times 10^{+2}$ $0.14285 \times 10^{+2}$ $0.13196 \times 10^{+2}$ $0.12009 \times 10^{+2}$ $0.12791 \times 10^{+2}$ $0.16760 \times 10^{+2}$ $0.22352 \times 10^{+2}$ $0.30389 \times 10^{+2}$ $0.54056 \times 10^{+2}$ $0.58410 \times 10^{+2}$ $0.19337 \times 10^{+3}$

$0.21980 \times 10^{+2}$ $0.18657 \times 10^{+2}$ $0.15721 \times 10^{+2}$ $0.15812 \times 10^{+2}$ $0.17039 \times 10^{+2}$
$0.11763 \times 10^{+4}$ $0.37947 \times 10^{+4}$ $0.25947 \times 10^{+4}$ $0.22997 \times 10^{+4}$ $0.19426 \times 10^{+4}$ $0.12821 \times 10^{+4}$ $0.99983 \times 10^{+3}$ $0.86870 \times 10^{+3}$ $0.77032 \times 10^{+3}$ $0.70668 \times 10^{+3}$ $0.62395 \times 10^{+3}$ $0.70539 \times 10^{+3}$ $0.43031 \times 10^{+3}$

$0.91195 \times 10^{+3}$ $0.14028 \times 10^{+4}$ $0.13177 \times 10^{+4}$ $0.11804 \times 10^{+4}$ $0.13313 \times 10^{+4}$ $0.17460 \times 10^{+4}$ $0.18346 \times 10^{+4}$ $0.12724 \times 10^{+4}$ $0.10608 \times 10^{+4}$ $0.65201 \times 10^{+3}$ $0.48131 \times 10^{+3}$ $0.46546 \times 10^{+3}$ $0.51341 \times 10^{+3}$ $0.70296 \times 10^{+3}$ $0.56073 \times 10^{+3}$

$0.55031 \times 10^{+3}$ $0.59483 \times 10^{+3}$ $0.77606 \times 10^{+3}$ $0.14180 \times 10^{+4}$ $0.17359 \times 10^{+4}$ $0.20839 \times 10^{+4}$ $0.24488 \times 10^{+4}$ $0.22271 \times 10^{+4}$ $0.13505 \times 10^{+4}$ $0.82498 \times 10^{+3}$ $0.76406 \times 10^{+3}$ $0.52415 \times 10^{+3}$ $0.62641 \times 10^{+3}$ $0.47377 \times 10^{+3}$

$0.87083 \times 10^{+3}$ $0.74656 \times 10^{+3}$ $0.84576 \times 10^{+3}$ $0.10227 \times 10^{+4}$ $0.12168 \times 10^{+4}$ $0.14260 \times 10^{+4}$ $0.25044 \times 10^{+4}$ $0.16523 \times 10^{+4}$ $0.77646 \times 10^{+3}$ $0.87345 \times 10^{+3}$ $0.62115 \times 10^{+3}$ $0.50094 \times 10^{+3}$ $0.52657 \times 10^{+3}$ $0.38507 \times 10^{+3}$

$0.78627 \times 10^{+3}$ $0.18782 \times 10^{+4}$ $0.19472 \times 10^{+4}$ $0.22301 \times 10^{+4}$ $0.27064 \times 10^{+4}$

$70.5 \pm 2.5$

$175.3 \pm 2.1$

$156.1 \pm 2.1$

$145.2 \pm 1.8$

$137.0 \pm 1.7$

$124.7 \pm 1.4$

$115.0 \pm 1.2$

$114.0 \pm 1.3$

$131.6 \pm 1.6$

$167.6 \pm 2.6$

$143.0 \pm 1.8$

$154.8 \pm 1.7$

$175.1 \pm 3.4$

$115.8 \pm 5.3$

$130.3 \pm 3.9$

$144.3 \pm 2.6$

$145.1 \pm 3.5$

$136.2 \pm 2.9$

$138.3 \pm 1.9$

$141.1 \pm 1.8$

$138.9 \pm 1.7$

$146.8 \pm 1.8$

$142.5 \pm 2.9$

$141.3 \pm 3.6$

$150.5 \pm 3.1$

$153.1 \pm 2.2$

$161.4 \pm 1.8$

$174.9 \pm 2.0$

$33.7 \pm 2.2$

$54.5 \pm 1.4$

$68.0 \pm 1.1$

$79.8 \pm 0.9$

$78.2 \pm 0.9$

$76.3 \pm 0.9$ 


\begin{tabular}{|c|c|c|c|c|c|c|c|c|}
\hline$T\left({ }^{\circ} \mathrm{C}\right)$ & cum. ${ }^{39} \mathrm{Ar}_{\mathrm{K}}$ & $\begin{array}{l}\text { Atmos. } \\
(\%)\end{array}$ & ${ }^{36} \mathrm{Ar} /{ }^{39} \mathrm{Ar}$ & ${ }^{37} \mathrm{Ar} /{ }^{39} \mathrm{Ar}$ & ${ }^{38} \mathrm{Ar} /{ }^{39} \mathrm{Ar}$ & ${ }^{40} \mathrm{Ar} /{ }^{39} \mathrm{Ar}$ & ${ }^{40} \mathrm{Ar} /{ }^{36} \mathrm{Ar}$ & $\begin{array}{l}\text { Date } \\
\text { (Ma) }\end{array}$ \\
\hline 780 & 0.390 & 7.070 & $0.42561 \times 10^{-2}$ & 0.19120 & $0.17528 \times 10^{-1}$ & $0.17613 \times 10^{+2}$ & $0.41384 \times 10^{+4}$ & $87.6 \pm 1.0$ \\
\hline 840 & 0.507 & 6.628 & $0.41112 \times 10^{-2}$ & 0.22265 & $0.18746 \times 10^{-1}$ & $0.18106 \times 10^{+2}$ & $0.44040 \times 10^{+4}$ & $90.4 \pm 1.1$ \\
\hline 900 & 0.619 & 14.632 & $0.90336 \times 10^{-2}$ & 0.30563 & $0.21545 \times 10^{-1}$ & $0.18116 \times 10^{+2}$ & $0.20054 \times 10^{+4}$ & $82.9 \pm 0.9$ \\
\hline 950 & 0.730 & 20.661 & $0.12922 \times 10^{-1}$ & 0.37251 & $0.24231 \times 10^{-1}$ & $0.18374 \times 10^{+2}$ & $0.14219 \times 10^{+4}$ & $78.3 \pm 0.9$ \\
\hline 1000 & 0.788 & 23.149 & $0.18864 \times 10^{-1}$ & 0.67305 & $0.31985 \times 10^{-1}$ & $0.23890 \times 10^{+2}$ & $0.12664 \times 10^{+4}$ & $98.1 \pm 1.2$ \\
\hline 1040 & 0.849 & 34.634 & $0.27894 \times 10^{-1}$ & 0.55637 & $0.34732 \times 10^{-1}$ & $0.23707 \times 10^{+2}$ & $0.84990 \times 10^{+3}$ & $83.1 \pm 0.9$ \\
\hline 1080 & 0.944 & 32.770 & $0.31649 \times 10^{-1}$ & $0.10305 \times 10^{+1}$ & $0.42132 \times 10^{-1}$ & $0.28331 \times 10^{+2}$ & $0.89516 \times 10^{+3}$ & $101.7 \pm 1.2$ \\
\hline 1120 & 0.973 & 40.339 & $0.74268 \times 10^{-1}$ & $0.17124 \times 10^{+1}$ & $0.66378 \times 10^{-1}$ & $0.54113 \times 10^{+2}$ & $0.72862 \times 10^{+3}$ & $169.3 \pm 2.3$ \\
\hline 1160 & 0.978 & 83.437 & 0.66212 & 0.88287 & 0.22903 & $0.23445 \times 10^{+3}$ & $0.35408 \times 10^{+3}$ & $201.7 \pm 5.3$ \\
\hline 1200 & 1.000 & 64.634 & 0.20988 & $0.26428 \times 10^{+1}$ & $0.93410 \times 10^{-1}$ & $0.95674 \times 10^{+2}$ & $0.45586 \times 10^{+3}$ & $177.2 \pm 2.8$ \\
\hline \multicolumn{9}{|c|}{ XC7-2 Whole Rock ${ }^{\mathrm{s}}$} \\
\hline 400 & 0.029 & 27.008 & $0.97354 \times 10^{-2}$ & 0.11409 & $0.21407 \times 10^{-1}$ & $0.10649 \times 10^{+2}$ & $0.10938 \times 10^{+4}$ & $42.1 \pm 1.1$ \\
\hline 500 & 0.098 & 14.732 & $0.80235 \times 10^{-2}$ & $0.91300 \times 10^{-1}$ & $0.21681 \times 10^{-1}$ & $0.16076 \times 10^{+2}$ & $0.20036 \times 10^{+4}$ & $73.7 \pm 1.5$ \\
\hline 600 & 0.145 & 14.971 & $0.89609 \times 10^{-2}$ & 0.11871 & $0.22490 \times 10^{-1}$ & $0.17656 \times 10^{+2}$ & $0.19704 \times 10^{+4}$ & $80.5 \pm 1.3$ \\
\hline 660 & 0.179 & 11.910 & $0.79473 \times 10^{-2}$ & $0.98730 \times 10^{-1}$ & $0.19679 \times 10^{-1}$ & $0.19684 \times 10^{+2}$ & $0.24768 \times 10^{+4}$ & $92.7 \pm 1.2$ \\
\hline 720 & 0.216 & 17.130 & $0.12394 \times 10^{-1}$ & $0.61572 \times 10^{-1}$ & $0.17941 \times 10^{-1}$ & $0.21382 \times 10^{+2}$ & $0.17252 \times 10^{+4}$ & $94.7 \pm 1.1$ \\
\hline 780 & 0.297 & 18.493 & $0.13881 \times 10^{-1}$ & $0.46707 \times 10^{-1}$ & $0.17161 \times 10^{-1}$ & $0.22191 \times 10^{+2}$ & $0.15986 \times 10^{+4}$ & $96.6 \pm 1.1$ \\
\hline 840 & 0.425 & 15.828 & $0.11428 \times 10^{-1}$ & $0.54177 \times 10^{-1}$ & $0.17746 \times 10^{-1}$ & $0.21337 \times 10^{+2}$ & $0.18672 \times 10^{+4}$ & $95.9 \pm 1.0$ \\
\hline 900 & 0.588 & 9.202 & $0.61779 \times 10^{-2}$ & $0.73776 \times 10^{-1}$ & $0.19124 \times 10^{-1}$ & $0.19807 \times 10^{+2}$ & $0.32062 \times 10^{+4}$ & $96.1 \pm 1.0$ \\
\hline 950 & 0.776 & 8.230 & $0.53751 \times 10^{-2}$ & $0.90804 \times 10^{-1}$ & $0.20532 \times 10^{-1}$ & $0.19244 \times 10^{+2}$ & $0.35802 \times 10^{+4}$ & $94.4 \pm 1.0$ \\
\hline 1000 & 0.885 & 12.776 & $0.87581 \times 10^{-2}$ & 0.14596 & $0.25888 \times 10^{-1}$ & $0.20200 \times 10^{+2}$ & $0.23064 \times 10^{+4}$ & $94.2 \pm 1.0$ \\
\hline 1040 & 0.929 & 27.240 & $0.22148 \times 10^{-1}$ & 0.19837 & $0.39832 \times 10^{-1}$ & $0.24001 \times 10^{+2}$ & $0.10836 \times 10^{+4}$ & $93.4 \pm 1.1$ \\
\hline 1080 & 0.965 & 32.486 & $0.32394 \times 10^{-1}$ & 0.54871 & $0.63327 \times 10^{-1}$ & $0.29367 \times 10^{+2}$ & $0.90657 \times 10^{+3}$ & $105.7 \pm 1.2$ \\
\hline 1120 & 0.985 & 49.049 & $0.70530 \times 10^{-1}$ & $0.11819 \times 10^{+1}$ & $0.89805 \times 10^{-1}$ & $0.42339 \times 10^{+2}$ & $0.60029 \times 10^{+3}$ & $114.8 \pm 1.4$ \\
\hline 1160 & 0.996 & 63.515 & 0.14842 & $0.12365 \times 10^{+1}$ & 0.12090 & $0.68932 \times 10^{+2}$ & $0.46445 \times 10^{+3}$ & $133.2 \pm 2.2$ \\
\hline 1200 & 1.000 & 69.677 & 0.41931 & 0.99860 & 0.20657 & $0.17775 \times 10^{+3}$ & $0.42391 \times 10^{+3}$ & $274.3 \pm 5.4$ \\
\hline \multicolumn{9}{|c|}{ XC8-6 Whole Rock ${ }^{\mathrm{t}}$} \\
\hline 400 & 0.020 & 29.825 & $0.16890 \times 10^{-1}$ & 0.25017 & $0.22232 \times 10^{-1}$ & $0.16700 \times 10^{+2}$ & $0.98872 \times 10^{+3}$ & $63.2 \pm 1.7$ \\
\hline 500 & 0.055 & 32.175 & $0.18887 \times 10^{-1}$ & 0.24668 & $0.25961 \times 10^{-1}$ & $0.17317 \times 10^{+2}$ & $0.91687 \times 10^{+3}$ & $63.3 \pm 1.8$ \\
\hline 600 & 0.121 & 27.728 & $0.14126 \times 10^{-1}$ & 0.21728 & $0.38724 \times 10^{-1}$ & $0.15024 \times 10^{+2}$ & $0.10636 \times 10^{+4}$ & $58.6 \pm 3.5$ \\
\hline 660 & 0.162 & 22.981 & $0.10945 \times 10^{-1}$ & 0.22296 & $0.35630 \times 10^{-1}$ & $0.14029 \times 10^{+2}$ & $0.12818 \times 10^{+4}$ & $58.3 \pm 1.9$ \\
\hline 720 & 0.201 & 24.071 & $0.12164 \times 10^{-1}$ & 0.16993 & $0.29909 \times 10^{-1}$ & $0.14908 \times 10^{+2}$ & $0.12256 \times 10^{+4}$ & $61.0 \pm 1.0$ \\
\hline 780 & 0.266 & 19.684 & $0.93524 \times 10^{-2}$ & 0.12181 & $0.21830 \times 10^{-1}$ & $0.14022 \times 10^{+2}$ & $0.14993 \times 10^{+4}$ & $60.7 \pm 0.9$ \\
\hline 840 & 0.398 & 15.048 & $0.68384 \times 10^{-2}$ & 0.10568 & $0.19019 \times 10^{-1}$ & $0.13405 \times 10^{+2}$ & $0.19602 \times 10^{+4}$ & $61.4 \pm 0.7$ \\
\hline 900 & 0.561 & 9.677 & $0.41661 \times 10^{-2}$ & 0.14171 & $0.18630 \times 10^{-1}$ & $0.12641 \times 10^{+2}$ & $0.30341 \times 10^{+4}$ & $61.5 \pm 0.7$ \\
\hline 950 & 0.718 & 10.715 & $0.47215 \times 10^{-2}$ & 0.20696 & $0.21354 \times 10^{-1}$ & $0.12904 \times 10^{+2}$ & $0.27330 \times 10^{+4}$ & $62.1 \pm 0.7$ \\
\hline 1000 & 0.819 & 18.693 & $0.10584 \times 10^{-1}$ & 0.40150 & $0.31531 \times 10^{-1}$ & $0.16597 \times 10^{+2}$ & $0.15682 \times 10^{+4}$ & $72.5 \pm 0.8$ \\
\hline 1040 & 0.870 & 35.917 & $0.29437 \times 10^{-1}$ & 0.81910 & $0.48619 \times 10^{-1}$ & $0.24075 \times 10^{+2}$ & $0.81786 \times 10^{+3}$ & $82.8 \pm 1.2$ \\
\hline 1080 & 0.927 & 42.130 & $0.39078 \times 10^{-1}$ & $0.10580 \times 10^{+1}$ & $0.56602 \times 10^{-1}$ & $0.27248 \times 10^{+2}$ & $0.69728 \times 10^{+3}$ & $84.6 \pm 0.9$ \\
\hline 1120 & 0.956 & 48.732 & $0.72931 \times 10^{-1}$ & $0.12656 \times 10^{+1}$ & $0.75795 \times 10^{-1}$ & $0.44057 \times 10^{+2}$ & $0.60409 \times 10^{+3}$ & $120.0 \pm 1.4$ \\
\hline 1160 & 0.990 & 49.238 & $0.84625 \times 10^{-1}$ & $0.12010 \times 10^{+1}$ & $0.85323 \times 10^{-1}$ & $0.50632 \times 10^{+2}$ & $0.59831 \times 10^{+3}$ & $136.0 \pm 1.7$ \\
\hline 1200 & 1.000 & 78.118 & 0.37071 & $0.10245 \times 10^{+1}$ & 0.14360 & $0.14016 \times 10^{+3}$ & $0.37808 \times 10^{+3}$ & $161.1 \pm 4.2$ \\
\hline \multicolumn{9}{|c|}{ XC9-2 Whole Rock ${ }^{\mathrm{u}}$} \\
\hline 400 & 0.033 & 30.854 & $0.12632 \times 10^{-1}$ & 0.17261 & $0.35090 \times 10^{-1}$ & $0.12085 \times 10^{+2}$ & $0.95668 \times 10^{+3}$ & $45.2 \pm 1.8$ \\
\hline 500 & 0.083 & 15.895 & $0.85673 \times 10^{-2}$ & 0.14349 & $0.33009 \times 10^{-1}$ & $0.15888 \times 10^{+2}$ & $0.18545 \times 10^{+4}$ & $71.8 \pm 2.2$ \\
\hline 600 & 0.126 & 24.491 & $0.14516 \times 10^{-1}$ & 0.16110 & $0.38200 \times 10^{-1}$ & $0.17493 \times 10^{+2}$ & $0.12051 \times 10^{+4}$ & $71.0 \pm 2.5$ \\
\hline 660 & 0.164 & 12.842 & $0.86605 \times 10^{-2}$ & 0.14832 & $0.20101 \times 10^{-1}$ & $0.19870 \times 10^{+2}$ & $0.22943 \times 10^{+4}$ & $92.6 \pm 1.0$ \\
\hline 720 & 0.211 & 13.365 & $0.91968 \times 10^{-2}$ & 0.11254 & $0.17896 \times 10^{-1}$ & $0.20299 \times 10^{+2}$ & $0.22072 \times 10^{+4}$ & $94.0 \pm 1.1$ \\
\hline 780 & 0.281 & 8.899 & $0.59445 \times 10^{-2}$ & $0.93992 \times 10^{-1}$ & $0.17811 \times 10^{-1}$ & $0.19687 \times 10^{+2}$ & $0.33119 \times 10^{+4}$ & $95.8 \pm 1.0$ \\
\hline 840 & 0.384 & 7.037 & $0.44548 \times 10^{-2}$ & 0.10165 & $0.22247 \times 10^{-1}$ & $0.18626 \times 10^{+2}$ & $0.41811 \times 10^{+4}$ & $92.6 \pm 1.4$ \\
\hline 900 & 0.519 & 5.177 & $0.32026 \times 10^{-2}$ & 0.11487 & $0.20158 \times 10^{-1}$ & $0.18143 \times 10^{+2}$ & $0.56652 \times 10^{+4}$ & $92.0 \pm 1.0$ \\
\hline 950 & 0.689 & 6.279 & $0.39684 \times 10^{-2}$ & 0.12388 & $0.21283 \times 10^{-1}$ & $0.18557 \times 10^{+2}$ & $0.46760 \times 10^{+4}$ & $93.0 \pm 1.0$ \\
\hline 1000 & 0.792 & 15.759 & $0.11066 \times 10^{-1}$ & 0.18573 & $0.27107 \times 10^{-1}$ & $0.20691 \times 10^{+2}$ & $0.18697 \times 10^{+4}$ & $93.2 \pm 1.0$ \\
\hline 1040 & 0.870 & 26.506 & $0.20859 \times 10^{-1}$ & 0.18602 & $0.31548 \times 10^{-1}$ & $0.23230 \times 10^{+2}$ & $0.11137 \times 10^{+4}$ & $91.3 \pm 1.0$ \\
\hline 1080 & 0.958 & 28.216 & $0.25963 \times 10^{-1}$ & 0.56409 & $0.48210 \times 10^{-1}$ & $0.27069 \times 10^{+2}$ & $0.10426 \times 10^{+4}$ & $103.6 \pm 1.1$ \\
\hline 1120 & 0.985 & 41.156 & $0.61347 \times 10^{-1}$ & $0.12398 \times 10^{+1}$ & $0.74260 \times 10^{-1}$ & $0.43850 \times 10^{+2}$ & $0.71477 \times 10^{+3}$ & $136.5 \pm 1.7$ \\
\hline 1160 & 0.995 & 64.598 & 0.18543 & $0.14193 \times 10^{+1}$ & 0.11876 & $0.84689 \times 10^{+2}$ & $0.45671 \times 10^{+3}$ & $157.7 \pm 2.1$ \\
\hline 1200 & 1.000 & 78.343 & 0.49456 & $0.11243 \times 10^{+1}$ & 0.21576 & $0.18646 \times 10^{+3}$ & $0.37703 \times 10^{+3}$ & $209.3 \pm 2.8$ \\
\hline
\end{tabular}

Note: $J$-values: Weighted mean of three fusions of irradiation standard LP-6 Biotite having a calibrated ${ }^{40} \mathrm{Ar} /{ }^{39} \mathrm{Ar}$ age of $128.4 \pm 0.2 \mathrm{Ma}$, based on Fish Canyon Sanidine (28.02 $\pm 0.28 \mathrm{Ma}$ ) (Baksi et al., 1996; Renne et al., 1998).; $T^{\circ} \mathrm{C}=$ temperature with uncertainty of $\pm 2{ }^{\circ} \mathrm{C}$; The date is obtained by using the following equations: Date $=(1 / \lambda) \ln \left(1+J\left({ }^{40} \mathrm{Ar}^{*} \beta^{39} \mathrm{Ar} r_{k}\right)\right)$, and $\left.{ }^{40} \mathrm{Ar}^{*} /{ }^{39} \mathrm{Ar}_{k}=\left(\left[{ }^{40} \mathrm{Ar} /{ }^{39} \mathrm{Ar}\right]_{m}-295.5\left[{ }^{36} \mathrm{Ar} /{ }^{39} \mathrm{Ar}\right]_{m}+295.5\left[{ }^{36} \mathrm{Ar} /{ }^{37} \mathrm{Ar}\right]_{C a}{ }^{37} \mathrm{Ar}{ }^{39} \mathrm{Ar}\right]_{m}\right) /\left(1-\left[{ }^{39}\right.\right.$ $\left.\left.\left.\mathrm{Ar} /{ }^{37} \mathrm{Ar}\right]_{\mathrm{Ca}}{ }^{37} \mathrm{Ar} /{ }^{39} \mathrm{Ar}\right]_{m}\right)-\left[{ }^{40} \mathrm{Ar} /{ }^{39} \mathrm{Ar}\right]_{k}$, where []$_{\mathrm{Ca}}$ and []$_{\mathrm{K}=}$ isotope ratios of argon extracted from irradiated calcium and potassium salts (values cited in the text) and []$_{\mathrm{m}}=$ isotope ratio of argon extracted from irradiated unknown; Date $(\mathrm{Ma})=$ the date calculated using the following decay constants: $\lambda_{\varepsilon}=0.581 \times 10^{-10} \mathrm{yr}^{-1} ; \lambda_{\beta}=4.962 \times 10^{-10} \mathrm{yr}^{-1} ; \lambda=5.543 \times 10^{-10} \mathrm{yr}^{-1} ;{ }^{40} \mathrm{~K} / \mathrm{K}=0.01167$ atom \% (Steiger and Jäger, 1977); Cum. ${ }^{39} \mathrm{Ar}=\mathrm{cumulative}$ fractions of ${ }^{39} \mathrm{Ar}_{K}$; The quoted error is one standard deviation, including the error in the $J$-value but not for the errors in the interference corrections; Integrated Date $=$ the date and error calculated from the sum total gas from all steps; Plateau Date $=$ the data and error calculated from the sum total gas from those steps, the ages of which fall within 2 S.D. of each other. 
${ }^{\text {a } ~} J$-value $=0.00304509 \pm 0.00003178 ;$ Integrated date $=143.3 \pm 1.5 \mathrm{Ma} ;$ Plateau date $=139.8 \pm 1.5 \mathrm{Ma}\left(600-1050{ }^{\circ} \mathrm{C}\right)$.

b $J$-value $=0.00304509 \pm 0.00003178 ;$ Integrated date $=99.2 \pm 1.0 \mathrm{Ma} ;$ Plateau date $=100.9 \pm 1.1 \mathrm{Ma}\left(600-1050{ }^{\circ} \mathrm{C}\right)$.

c $J$-value $=0.00304509 \pm 0.00003178$; Integrated date $=96.3 \pm 1.0 \mathrm{Ma}$; Plateau date $=96.7 \pm 1.0 \mathrm{Ma}\left(650-1050{ }^{\circ} \mathrm{C}\right)$.

d $J$-value $=0.00304509 \pm 0.00003178 ;$ Integrated date $=72.0 \pm 0.8 \mathrm{Ma}$.

e $J$-value $=0.00304509 \pm 0.00003178 ;$ Integrated date $=143.1 \pm 1.4 \mathrm{Ma} ;$ Plateau date $=146.9 \pm 1.5 \mathrm{Ma}\left(740-1150{ }^{\circ} \mathrm{C}\right)$.

f $J$-value $=0.00304509 \pm 0.00003178 ;$ Integrated date $=43.9 \pm 0.5 \mathrm{Ma}$; Plateau date $=45.7 \pm 0.5 \mathrm{Ma}\left(780-1090{ }^{\circ} \mathrm{C}\right)$.

g $J$-value $=0.00304509 \pm 0.00003178 ;$ Integrated date $=71.7 \pm 0.8 \mathrm{Ma}$; Plateau date $=70.9 \pm 0.8 \mathrm{Ma}\left(720-1040{ }^{\circ} \mathrm{C}\right)$.

h $J$-value $=0.00304509 \pm 0.00003178 ;$ Integrated date $=66.4 \pm 0.7 \mathrm{Ma}$.

i $J$-value $=0.00304509 \pm 0.00003178 ;$ Integrated date $=52.7 \pm 0.7 \mathrm{Ma}$; Plateau date $=53.1 \pm 0.6 \mathrm{Ma}\left(780-1040{ }^{\circ} \mathrm{C}\right)$.

j $J$-value $=0.00304509 \pm 0.00003178 ;$ Integrated date $=173.4 \pm 1.9 \mathrm{Ma}$

k $J$-value $=0.00304509 \pm 0.00003178 ;$ Integrated date $=87.7 \pm 0.9 \mathrm{Ma}$.

${ }^{1} J$-value $=0.00304509 \pm 0.00003178 ;$ Integrated date $=199.7 \pm 2.3 \mathrm{Ma}$.

$\mathrm{m} J$-value $=0.00304509 \pm 0.00003178 ;$ Integrated date $=148.4 \pm 3.0 \mathrm{Ma}$

${ }^{n} J$-value $=0.00304509 \pm 0.00003178 ;$ Integrated date $=136.4 \pm 1.4 \mathrm{Ma}$.

${ }^{\circ} \mathrm{J}$-value $=0.00304509 \pm 0.00003178 ;$ Integrated date $=147.4 \pm 1.6 \mathrm{Ma}$; Plateau date $=143.3 \pm 1.6 \mathrm{Ma}\left(600-1120{ }^{\circ} \mathrm{C}\right)$.

p $J$-value $=0.00304509 \pm 0.00003178 ;$ Integrated date $=80.2 \pm 0.8 \mathrm{Ma}$; Plateau date $=76.9 \pm 0.8 \mathrm{Ma}\left(720-1080{ }^{\circ} \mathrm{C}\right)$.

q $J$-value $=0.00304509 \pm 0.00003178 ;$ Integrated date $=66.9 \pm 0.7 \mathrm{Ma}$; Plateau date $=56.8 \pm 0.6 \mathrm{Ma}\left(660-1000{ }^{\circ} \mathrm{C}\right)$.

${ }^{\mathrm{r}} J$-value $=0.00304509 \pm 0.00003178 ;$ Integrated date $=90.3 \pm 0.9 \mathrm{Ma}$.

s $J$-value $=0.00304509 \pm 0.00003178 ;$ Integrated date $=93.4 \pm 1.0 \mathrm{Ma}$; Plateau date $=95.1 \pm 1.0 \mathrm{Ma}\left(660-1040{ }^{\circ} \mathrm{C}\right)$.

${ }^{\mathrm{t}} J$-value $=0.00304509 \pm 0.00003178 ;$ Integrated date $=70.1 \pm 0.8 \mathrm{Ma}$; Plateau date $=61.2 \pm 0.7 \mathrm{Ma}\left(400-900{ }^{\circ} \mathrm{C}\right)$.

u $J$-value $=0.00304509 \pm 0.00003178 ;$ Integrated date $=92.8 \pm 1.0 \mathrm{Ma} ;$ Plateau date $=92.9 \pm 1.0 \mathrm{Ma}\left(660-1040{ }^{\circ} \mathrm{C}\right)$.

\section{References}

Ali, J.R., Thompson, G.M., Song, X., Wang, Y., 2002. Emeishan Basalts (SW China) and the 'end-Guadalupian' crisis: magnetobiostratigraphic constraints. Journal of the Geological Society, London 159, 21-29.

Arne, D., Worley, B., Wilson, C., Chen, S.F., Foster, D., Luo, Z.L., Liu, S.G., Dirks, P., 1997. Differential exhumation in response to episodic thrusting along the eastern margin of the Tibetan Plateau. Tectonophysics 280, 239-256.

Baksi, A.K., Archibald, D.A., Farrar, E., 1996. Intercalibration of ${ }^{40} \mathrm{Ar} /{ }^{39} \mathrm{Ar}$ dating standards. Chemical Geology 129, 307-324.

Boven, A., Pasteels, P., Punzalan, L.E., Liu, J., Luo, X., Zhang, W., Guo, Z., Hertogen, J., 2002. ${ }^{40} \mathrm{Ar} /{ }^{39} \mathrm{Ar}$ geochronological constraints on the age and evolution of Permo-Triassic Emeishan Volcanic Province, Southwest China. Journal of Asian Earth Sciences 20, 157-175.

Burchfiel, B.C., Chen, Z., Liu, Y., Royden, L.H., 1995. Tectonics of the Longmen Shan and adjacent regions, central China. International Geology Review 37, 661-736.

Chang, E.Z., 2000. Geology and tectonics of the Songpan-Ganzi fold belt, southwestern China. International Geology Review 42, 813-834.

Chen, S.F., Wilson, C.J.L., 1996. Emplacement of the Longmen Mountains Thrust-Nappe Belt along the eastern margin of the Tibetan Plateau. Journal of Structural Geology 18, 413-430.

Chen, S.F., Wilson, C.J.L., Worley, B.A., 1995. Tectonic transition from the Songpan-Garze Fold Belt to the Sichuan Basin, southwestern China. Basin Research 7, 235-253.

Chung, S.L., Jahn, B.M., 1995. Plume-lithosphere interaction in the generation of the Emeishan flood basalts at the Permian-Triassic boundary. Geology 23, 889-892.

Dmitriev, Y.I., Bogatikov, O.A., 1996. Emeishan flood basalts, Yangtze Platform: indicators of an aborted oceanic environment. Petrology 4, 407-418.

Enkin, R.J., Yang, Z., Chen, Y., Courtillot, V., 1992. Paleomagnetic constraints on the geodynamic history of the major blocks of China from the Permian to the present. Journal of geophysical Research 97B, $13953-13989$

Gilder, S., Courtillot, V., 1997. Timing of the north-south China collision from new middle to late Mesozoic paleomagnetic data from the north China block. Journal of Geophysical Research 102B, $17713-17727$.

Hall, R., 2002. Cenozoic geological and plate tectonic evolution of SE Asia and the SW Pacific: computer-based reconstructions, model and animations. Journal of Asian Earth Sciences 20, 353-431.
Hou, Z.Q., Chen, W., Lu, J.R., 2002. Collision event during 177-135 Ma on the eastern margin of the Qinghai-Tibet plateau: evidence from Ar40/Ar-39 dating for basalts on the western margin of the Yangtze platform. Acta Geologica Sinica-English Edition 76, 194-204.

Huang, K., Opdyke, N.D., 1998. Magnetostratigraphic investigations of an Emeishan basalt section in western Guizhou Province, China. Earth and Planetary Science Letters 163, 1-14.

Jin, Y., Shang, Q., 2000. The Permian of China and its interregional correlation. In: Yin, H., Dickins, J.M., Shi, G.R., Tong, J. (Eds.), Permo-Triassic evolution of Tethys and Western Circum-Pacific, pp. 71-98.

Leloup, P.H., Harrison, M., Ryerson, F.J., Chen, W., Li, Q., Tapponnier, P., Lacassin, R., 1993. Structural, petrological and thermal evolution of a Tertiary strike-slip shear zone, Diancang Shan, Yunnan. Journal of Geophysical Research 98B, 6715-6743.

Leloup, P.H., Lacassin, R., Tapponnier, P., Schärer, U., Dalai, Z., Xiaohan, L., Liangshang, Z., Shaocheng, J., Trinh, P.T., 1995. The Ailao ShanRed River shear zone (Yunnan, China), Tertiary transform boundary of Indochina. Tectonophysics 251, 3-84.

Leloup, P.H., Arnaud, N., Lacassin, R., Kienast, J.R., Harrison, T.M., Trong, T.P., Replumaz, A., Tapponnier, P., 2001. New constraints on the structure, thermochronology, and timing of the Ailao Shan-Red River shear zone, SE Asia. Journal of Geophysical Research 106B, $6683-6732$.

Liu, B., Xu, X., 1994. In: Liu, B., Xu, X. (Eds.), Atlas of the Lithofacies and Paleogeography of South China Sinian-Triassic, Science Press, Beijing, p. 192.

Lo, C.H., Lee, C.Y., 1994. ${ }^{40} \mathrm{Ar} /{ }^{39} \mathrm{Ar}$ method of $\mathrm{K}-\mathrm{Ar}$ age determination of geological samples using Tsing-Hua Open-pool (THOR) Reactor. Journal of the Geological Society of China 37, 143-164.

Lo, C.H., Chung, S.L., Lee, T.Y., Wu, G.Y., 2002. Age of the Emeishan flood magmatism and relations to Permian-Triassic boundary events. Earth and Planetary Science Letters 198, 449-458.

Luo, Z., Jin, Y., Zhao, X., 1990. The Emei taphrogenesis of the upper Yangtze Platform in south China. Geological Magazine 127, 393-405.

Metcalfe, I., 1999. Gondwana dispersion and Asian accretion: an overview. In: Metcalfe, I., (Ed.), Gondwana dispersion and Asian accretion, Final Results Volume for IGCP Project 321, A.A. Balkema, Rotterdam, pp. 9-28.

Nie, S., Yin, A., Rowley, D.B., Jin, Y., 1994. Exhumation of the Dabie Shan ultra-high pressure rocks and accumulation of the Songpan-Ganzi flysh sequence, central China. Geology 22, 990-1002.

Odin, G.S., 1982. Interlaboratory standards for dating purposes. In: Odin, G.S., (Ed.), Wiley, Chichester, pp. 123-149, 35 collaborators. 
Palmer, A.R., Geissman, J., 1999. 1999 Geologic time-scale. http://www. geosociety.org/science/timescale/timescl.htm.

Renne, P.R., Swisher, C.C., Deino, A.L., Karner, D.B., Owens, T.L., DePaolo, D.J., 1998. Intercalibration of standards, absolute ages and uncertainties in ${ }^{40} \mathrm{Ar} /{ }^{39} \mathrm{Ar}$ dating. Chemical Geology 145 , $117-152$.

Sheng, J., Jin, Y., 1994. Correlation of Permian deposits in China. Palaeoworld 4, 14-113.

Steiger, R.H., Jäger, E., 1977. Subcommission on geochronology: convention on the use of decay constants in geo- and cosmochronology. Earth and Planetary Science Letters 36, 359-362.

Thompson, G.M., Ali, J.R., Song, X.Y., Jolley, D.W., 2001. Emeishan Basalts, southwest China: reappraisal of the formation's type area stratigraphy and a discussion of its significance as a LIP. Journal of the Geological Society, London 158, 593-599.

Wang, E., Burchfiel, B.C., Royden, L.H., Chen, L., Chen, J., Li, W., Chen, Z., 1998a. Late Cenozoioc Xianshuihe-Xiaojiang, Red River, and Dali Fault systems of southwestern Sichuan and central Yunnan, China. Geological Society of America Special Paper 327, 108.

Wang, P.-L., Lo, C.-H., Lee, T.-Y., Chung, S.-L., Lan, C.-Y., Yem, N.T., 1998b. Thermochronological evidence for the movement of the Ailao Shan-Red River shear zone: a perspective from Vietnam. Geology 26 , 887-890.

Wang, P.-L., Lo, C.-H., Chung, S.-L., Lee, T.-Y., Lan, C.-Y., 2000a. Onset of the movement along the Ailao Shan-Red River shear zone: Constraint from ${ }^{40} \mathrm{Ar} /{ }^{39} \mathrm{Ar}$ dating results for Nam Dinh Area, northern Vietnam. Journal of Asian Earth Sciences 18, 85-96.
Wang, X., Metcalfe, I., Jian, P., He, L., Wang, C., 2000b. The JinshajiangAiloshan Suture Zone, China: tectonostratigraphy, age and evolution. Journal of Asian Earth Sciences 18, 675-690.

Xu, Y., Chung, S.L., Jahn, B.M., Wu, G., 2001. Petrologic and geochemical constraints on the petrogenesis of Permian-Triassic Emeishan flood basalts in southwestern China. Lithos 58, 145-168.

yan, D.P., Zhou, M.F., Song, H., Fu, Z., 2003. Stnictural style and tectonic significance of the Jianglang done in the eastern margin of the Tibetan Plateau, China. Stmctural Geology 25, 765-779.

Yokoyama, M., Liu, Y., Otofuji, Y., Yang, Z., 1999. New Late Jurassic palaeomagnetic data from the northern Sichuan basin: implications for deformation of the Yangtze craton. Geophysical Journal International $139,795-805$

York, D., 1969. Least-squares fitting of a straight line with correlated errors. Earth and Planetary Science Letters 5, 320-324.

Zhao, X., Coe, R.S., Gilder, S.A., Frost, G.M., 1996. Palaeomagnetic constraints on the palaeogeography of China: implications for Gondwanaland. Australian Journal of Earth Sciences 43, 643-672.

Zhou, M.F., Malpas, J., Song, X.Y., Robinson, P.T., Kennedy, A.K., Sun, M., Thompson, G., Yan, D.P., Zhang, C.J. SHRIMP zircon geochronology of the Emeishan large igneous province (SW China): implications for double mass extinctions in the Late Permian. Eleventh Goldschmidt Conference, Virginia, Abstract No. 20013519.

Zhou, M.F., Malpas, J., Song, X.Y., Robinson, P.T., Sun, M., Kennedy, A.K., Lesher, C.M., Keays, R.R., 2002. A temporal link between the Emeishan large igneous province (SW China) and the end-Guadalupian mass extinction. Earth and Planetary Science Letters 196, 113-122. 